DOE/RL-97-29

Rev. 0

\title{
Removal Design Report for the 108-F Biological Laboratory
}

Date Published

September 1997

United States

P.O. Box 550

Richland, Washington 99352

DISTRIBUTION OF THIS DOCUMENT IS UNLMME. 


\section{DISCLAIMER}

This report was prepared as an account of work sponsored by an agency of the United States Government. Neither the United States Government nor any agency thereof, nor any of their employees, makes any warranty, express or implied, or assumes any legal liability or responsibility for the accuracy, completeness, or usefulness of any information, apparatus, product, or process disclosed, or represents that its use would not infringe privately owned rights. Reference herein to any specific commercial product, process, or service by trade name, trademark, manufacturer, or otherwise does not necessarily constitute or imply its endorsement, recommendation, or favoring by the United States Government or any agency thereof. The views and opinions of authors expressed herein do not necessarily state or reflect those of the United States Government or any agency thereof. 


\section{DISCLAIMER}

Portions of this document may be illegible electronic image products. Images are produced from the best available original document. 
Rev. 0

\section{CONTENTS}

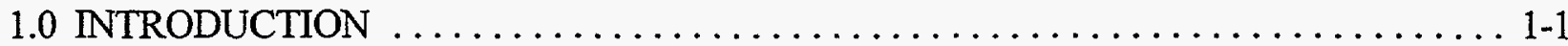

1.1 PURPOSE AND OBJECTIVE OF THE REMOVAL DESIGN REPORT $\ldots \ldots \ldots 1$-1

1.2 SCOPE AND GOALS OF THE REMOVAL ACTION $\ldots \ldots \ldots \ldots \ldots \ldots .1-6$

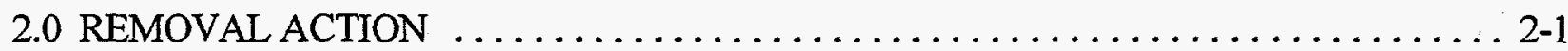

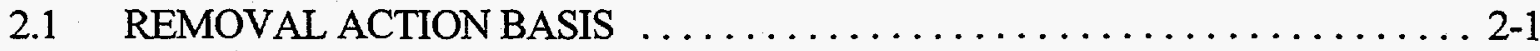

2.1.1 Site Mobilization and Preparation Work $\ldots \ldots \ldots \ldots \ldots \ldots \ldots \ldots . . \ldots \ldots . .1$

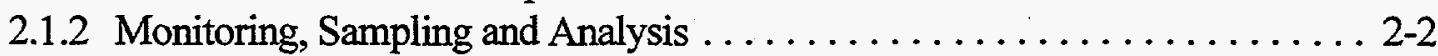

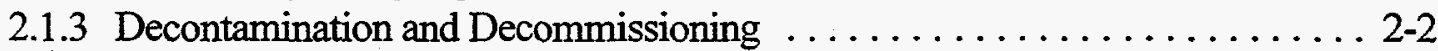

2.1.4 Disposal ...................................... 2-3

2.1.5 Site Restoration $\ldots \ldots \ldots \ldots \ldots \ldots \ldots \ldots \ldots \ldots \ldots \ldots \ldots \ldots \ldots \ldots \ldots \ldots \ldots \ldots, 3$

2.1.6 Demobilization ................................. 2-3

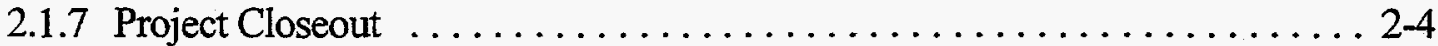

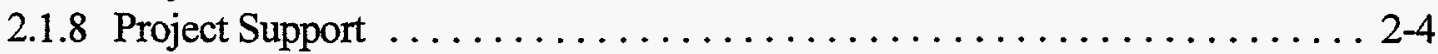

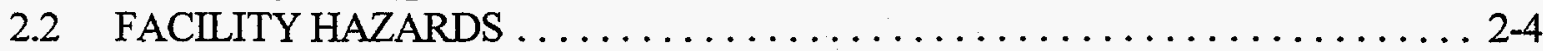

2.2.1 Hazardous Substances ............................. 2-4

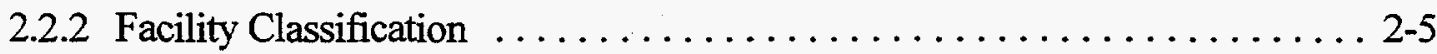

2.3 STRUCTURES, SYSTEMS, AND COMPONENTS THAT

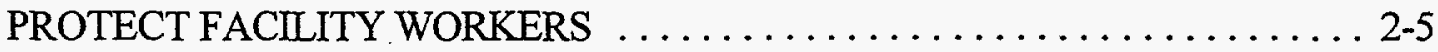

3.0 SAFETY AND HEALTH MANAGEMENT AND CONTROLS $\ldots \ldots \ldots \ldots \ldots \ldots \ldots$ 3-1

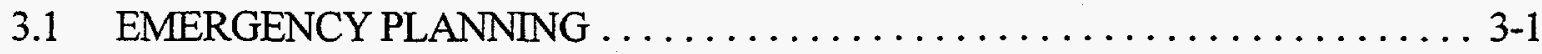

3.2 HEALTH AND SAFETY PROGRAM $\ldots \ldots \ldots \ldots \ldots \ldots \ldots \ldots \ldots \ldots \ldots \ldots \ldots \ldots, 1$

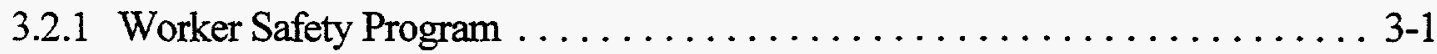

3.2.2 Site-Specific Health and Safety Plan $\ldots \ldots \ldots \ldots \ldots \ldots \ldots \ldots \ldots \ldots \ldots \ldots \ldots \ldots, 3-2$

3.2.3 ALARA Plans and Goals ............................. 3-2

3.3 MAINTENANCE MANAGEMENT $\ldots \ldots \ldots \ldots \ldots \ldots \ldots \ldots \ldots \ldots \ldots \ldots \ldots$

4.0 ENVIRONMENTAL MANAGEMENT AND CONTROLS $\ldots \ldots \ldots \ldots \ldots \ldots \ldots .4$.

4.1 APPLICABLE OR RELEVANT AND APPROPRIATE REQUIREMENTS . . . . 4 4-1

4.1.1 Other Criteria, Advisories, or Guidance to Be Considered for this Action . . . 4-3

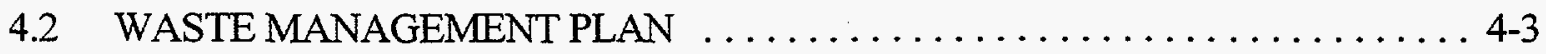

4.3 SAMPLING AND ANALYSIS PLAN $\ldots \ldots \ldots \ldots \ldots \ldots \ldots \ldots \ldots \ldots, 4,5$

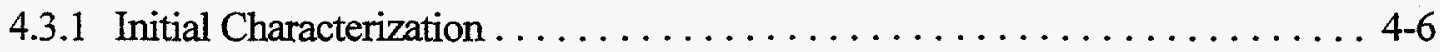

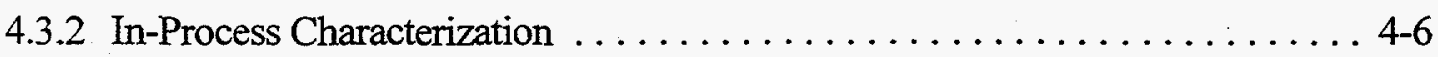

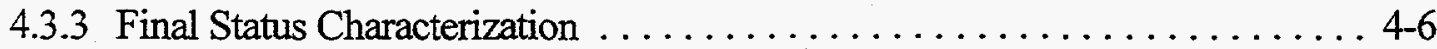

4.4 MITIGATION ACTION PLAN $\ldots \ldots \ldots \ldots \ldots \ldots \ldots \ldots \ldots \ldots \ldots, 4$

5.0 PROJECT MANAGEMENT AND ORGANIZATION $\ldots \ldots \ldots \ldots \ldots \ldots \ldots \ldots \ldots . . \ldots$

5.1 PROJECT SCHEDULE AND COST ESTIMATE $\ldots \ldots \ldots \ldots \ldots \ldots \ldots .5-1$

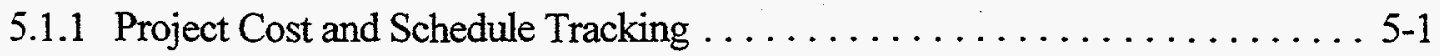

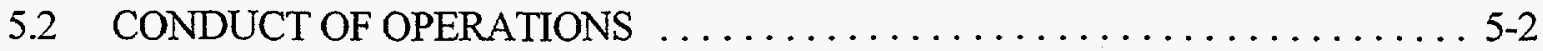


DOE/RL-97-29

Rev. 0

5.3 REMOVAL ACTION CHANGE MANAGEMENT $\ldots \ldots \ldots \ldots \ldots \ldots \ldots . . \ldots$

5.4 PERSONNEL TRAINING AND QUALIFICATIONS $\ldots \ldots \ldots \ldots \ldots \ldots \ldots .5$

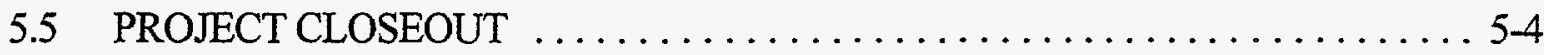

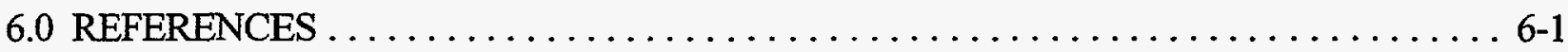

\section{APPENDICES}

A 108-F DECONTAMINATION AND

DECOMMISSIONING PROJECT SCHEDULE $\ldots \ldots \ldots \ldots \ldots \ldots \ldots \ldots \ldots$ A-1

B COST AND RESOURCES $\ldots \ldots \ldots \ldots \ldots \ldots \ldots \ldots \ldots \ldots \ldots \ldots \ldots \ldots \ldots \ldots \ldots \ldots \ldots \ldots$

\section{FIGURES}

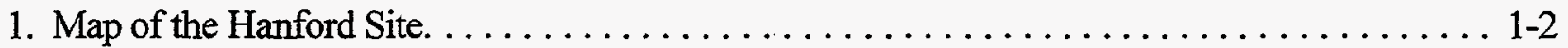

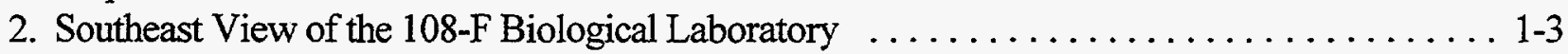

3. Northeast View of the $108-F$ Biological Laboratory $\ldots \ldots \ldots \ldots \ldots \ldots \ldots \ldots \ldots \ldots \ldots \ldots \ldots$

4. Map of the 100-F Area Showing Facilities Present During Reactor Operation .......... 1-5

5. Project Organization Chart for the 108-F Facility Project $\ldots \ldots \ldots \ldots \ldots \ldots \ldots \ldots \ldots \ldots \ldots \ldots$ 
Rev. 0

\section{ACRONYMS}

$\begin{array}{ll}\text { AAWP } & \text { asbestos abatement work plan } \\ \text { ACM } & \text { asbestos-containing material } \\ \text { ALARA } & \text { as low as reasonably achievable } \\ \text { ARAR } & \text { applicable or relevant and appropriate requirements } \\ \text { BARCT } & \text { best available radionuclide control technology } \\ \text { BHI } & \text { Bechtel Hanford, Inc. } \\ \text { CFR } & \text { Code of Federal Regulations } \\ \text { D\&D } & \text { decontamination and decommissioning } \\ \text { DOE } & \text { U.S. Department of Energy } \\ \text { EPA } & \text { U.S. Environmental Protection Agency } \\ \text { ERC } & \text { Environmental Restoration Contractor } \\ \text { ERDF } & \text { Environmental Restoration Disposal Facility } \\ \text { HASP } & \text { health and safety plan } \\ \text { OU } & \text { operable unit } \\ \text { PCB } & \text { polychlorinated biphenyl } \\ \text { PPE } & \text { personal protective equipment } \\ \text { RDR } & \text { removal design report } \\ \text { RWP } & \text { radiological work permit } \\ \text { S\&M } & \text { surveillance and maintenance } \\ \text { SHPO } & \text { State Historic Preservation Office } \\ \text { SS HASP } & \text { site-specific health and safety plan } \\ \text { WAC } & \text { Washington Administrative Code }\end{array}$


DOE/RL-97-29

Rev. 0

\subsection{INTRODUCTION}

The 100-F Area, site of the F Reactor, covers a total area of 256 hectares (632 acres) and is the furthest downstream of the reactor areas. Construction of the F Reactor began in December 1943 and operated from 1944 through 1965 . The 100-F Area originally had several major support facilities, including structures associated with the treatment and storage of reactor cooling water and support buildings for biological experimentation. Most of the 100-F facilities were deactivated with the reactor and have since been demolished. Of the dozen or so reactor-related structures, only the 105-F Reactor Building and the 108-F Biology Laboratory remain standing today. The 108-F Biological Laboratory is located within the 100-F Area (Operating Unit 100-FR-1) in the northeast corner of the site (see Figures 1 through 4).

The 108-F Biology Laboratory was intended to be used as a facility for the mixing and addition of chemicals used in the treatment of the reactor cooling water. Shortly after F Reactor began operation, it was determined that the facility was not needed for this purpose. In 1949, the building was converted for use as a biological laboratory. In 1962, the lab was expanded by adding a three-story annex to the original four-story structure. The resulting lab had a floor area of approximately $2,883 \mathrm{~m}^{2}\left(31,032 \mathrm{ft}^{2}\right)$ (main building and annex) that operated until 1973. The building contained 47 laboratories, a number of small offices, a conference room, administrative section, lunch and locker rooms, and a heavily shielded, high-energy exposure cell.

\subsection{PURPOSE AND OBJECTIVE OF THE REMOVAL DESIGN REPORT}

The purpose of this removal design report (RDR) is to establish the methods of decontamination and decommissioning (D\&D) and the supporting functions associated with facility removal and disposal. This RDR is prepared in accordance with Section 7.2.4 of the Hanford Federal Facility Agreement and Consent Order (Tri-Party Agreement) (Ecology et al. 1990).

The scope of work involved in this removal action includes the following:

- $\quad$ removing radioactive material

- $\quad$ removing hazardous substances

- $\quad$ removing facility equipment

- dismantling the facility structures

- disposing of waste products.

This RDR describes each task required and the implementation processes used to perform these activities. This RDR additionally identifies the regulatory guidelines, applicable orders, and procedures that will be used to direct and control the work activities. This document will serve as the decommissioning plan for the 108-F Facility. 
DOE/RL-97-29

Rev. 0

Figure 1. Map of the Hanford Site.

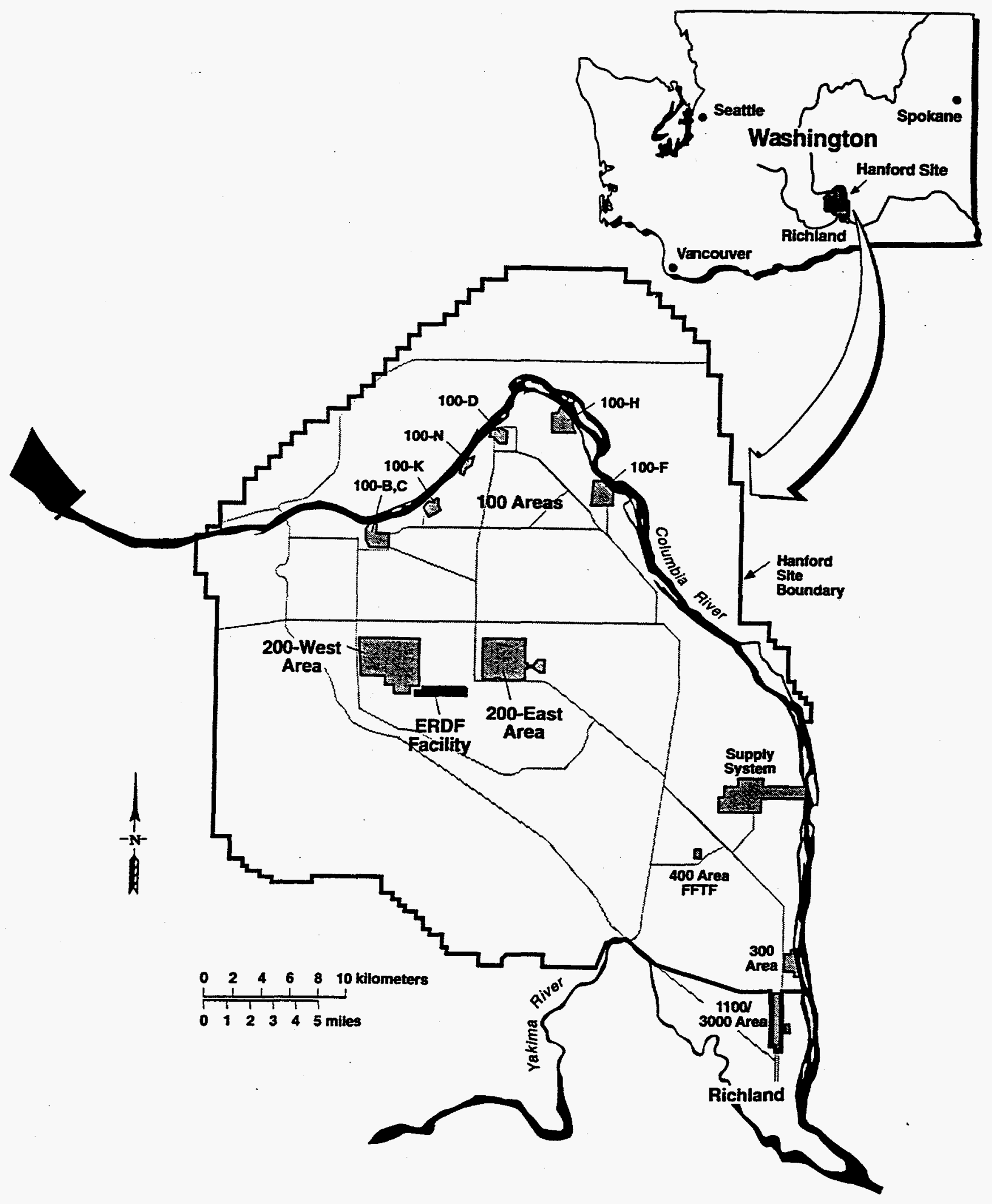


DOE/RL-97-29

Rev. 0

Figure 2. Southeast View of the 108-F Biological Laboratory.

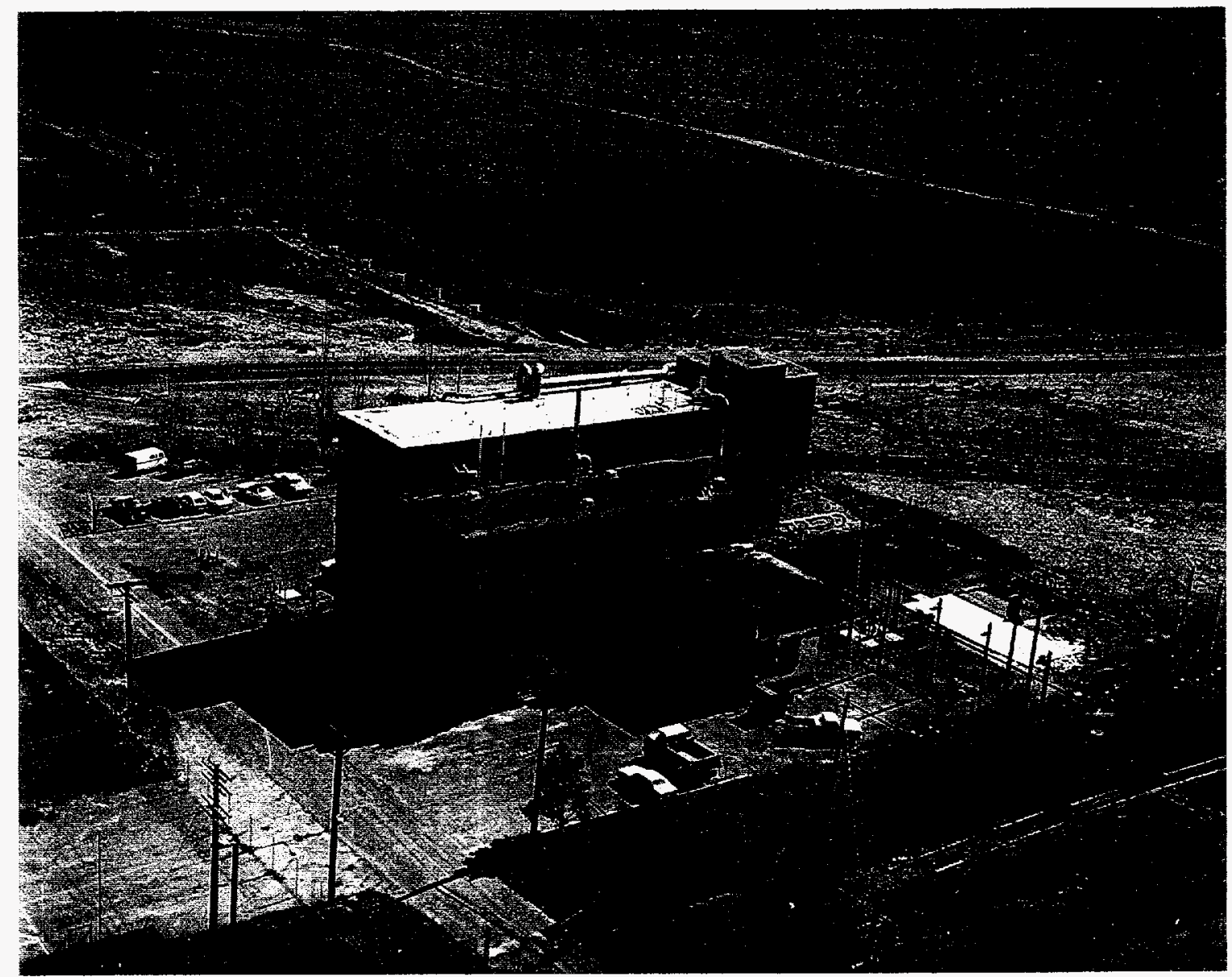

E9709058.1 
DOE/RL-97-29

Rev. 0

Figure 3. Northeast View of the 108-F Biological Laboratory.

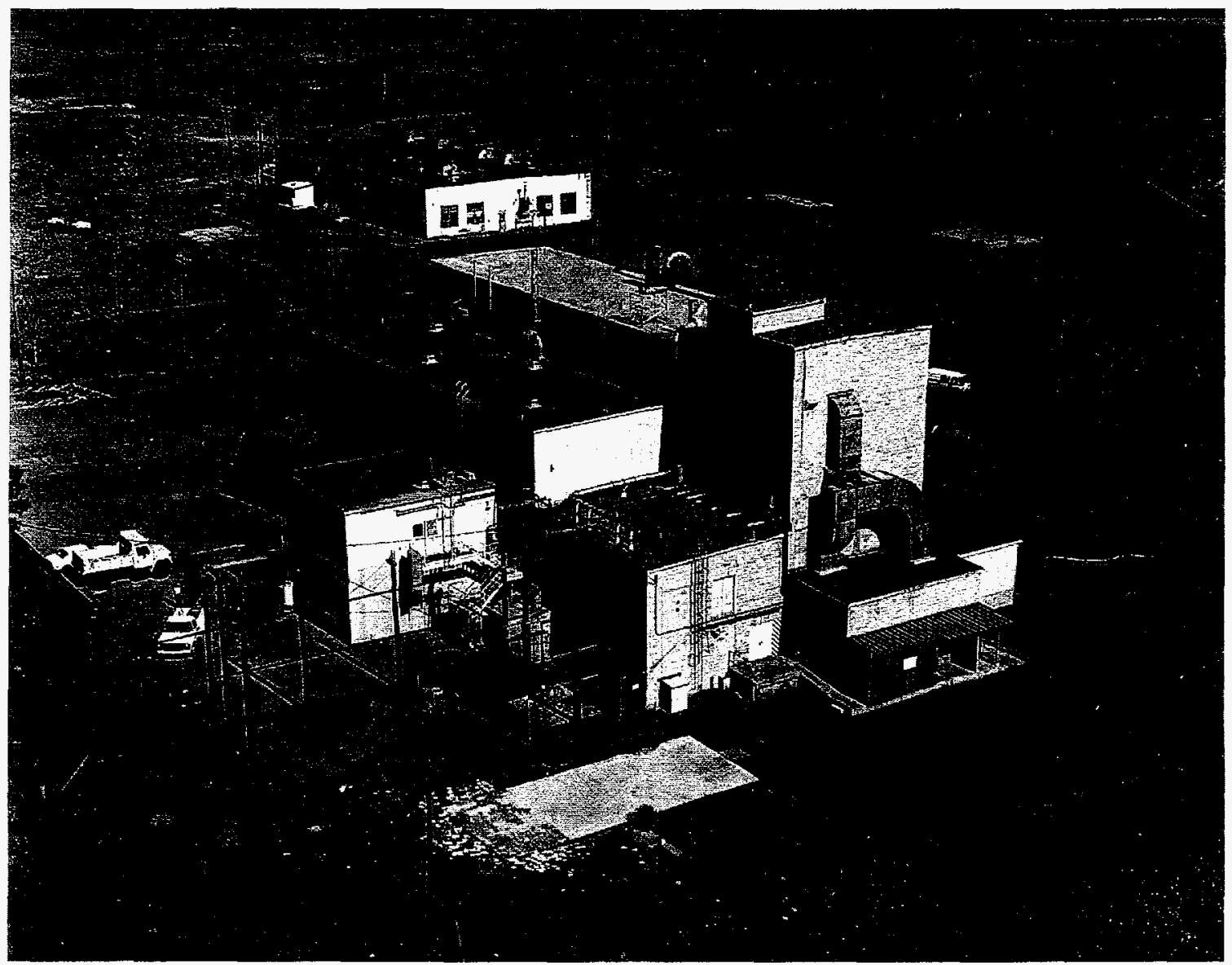

E9709058.2 
DOE/RL-97-29

Rev. 0

Figure 4. Map of the 100-F Area Showing Facilities Present During Reactor Operation.

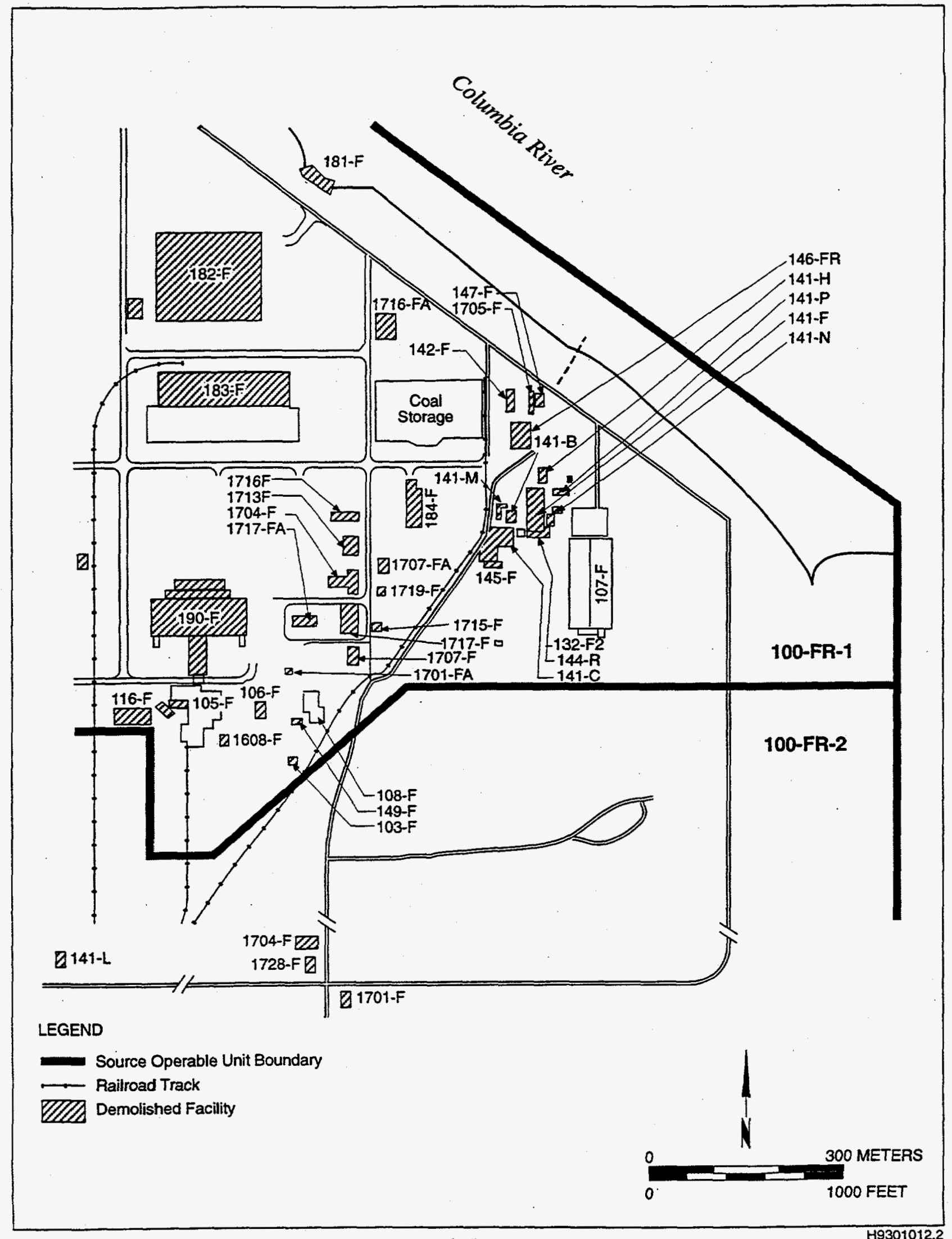


Rev. 0

The intent of this document is to identify the basis and provide direction for preparation of work packages for the project tasks. Field-level work packages will be developed to direct work activities, using the most recent information concerning facility conditions and instructing workers in the most applicable work methods. Existing procedures (as well as specifically developed instructions) will be used to perform and control the facility removal and disposal actions.

The 108-F D\&D Project's schedule presents the logical progression of events and their estimated durations (Appendix A). Cost and resources for the 108-F D\&D Project (Appendix B) have been developed. The project schedule is presented by fiscal year, and resources with associated costs are presented by activity. The logic of the schedule depicts a sequence of events that should be followed to ensure an effective and economic achievement of the project goals.

\subsection{SCOPE AND GOALS OF THE REMOVAL ACTION}

The Engineering Evaluation/Cost Analysis for the 100-B/C Area Ancillary Facilities at the 108-F Building (DOE/RL 1996) presents four alternative approaches for future facility management and the resultant levels of safety that may be anticipated. Decontamination and/or stabilization of the facility, followed by its demolition and disposal, were selected as the most responsive approach to ensure protection of human health and the environment, as documented in the action memorandum (EPA 1997) for the $100 \mathrm{~B} / \mathrm{C}$ Area ancillary facilities, the 108-F Facility, and final disposition of waste from the 105-C Interim Safe Storage Project.

Demolition, stabilization, and disposal will eliminate the 108-F Facility as a potential environmental hazard. In these operations, the waste products generated will be separated into a variety of waste streams, each of which will be disposed at appropriate disposal facilities.

The footprint of the facility and the affected surrounding terrain will be backfilled after completion of the removal action if the 108-F Facility cleanup standards are met. If cleanup of soils or subsurface structures from directly around the facility (i.e., french drains) is too extensive for cost effective and efficient removal, the site will be stabilized in a manner not to hinder future remediation. Future cleanup, if necessary, will be conducted at the same time as remedial action in the 100-FR-1 and 100-FR-02 Operable Unit (OU). Site restoration and revegetation will be coordinated with remedial actions and 100-F Area restoration actions. Characterization information for these areas will be generated to document the status of conditions at the conclusion of this project. 
DOE/RL-97-29

Rev. 0

\subsection{REMOVAL ACTION}

Section 2.0 presents the basis for the removal action; summarizes the hazards that have been identified for this removal action; and defines the structures, systems, and components that protect facility workers for necessary preventive and mitigative controls. Section 2.1 defines the work processes that will be used to decommission the 108-F Facility. Section 2.2 presents a summary of the hazards of the building and facility hazards classification. Section 2.3 describes the preventative features and commitments that are necessary for the protection of human health and the environment.

\subsection{REMOVAL ACTION BASIS}

The early elimination of hazardous substances and conditions will reduce the precautionary measures and safeguards needed to protect workers and the environment, and will permit the utilization of standard D\&D practices. The removal action objectives will achieve the following:

- Reduce the threat of release of hazardous substances contained within buildings and structures.

- Protect workers from hazards posed by these facilities.

- Minimize or eliminate surveillance and maintenance (S\&M) requirements and associated costs.

- Facilitate and be consistent with future remediation for the areas in which the facilities are located.

Throughout the project, material will be recycled whenever possible. All hazardous substances shall be handled in compliance with applicable or relevant and appropriate requirements (ARARs) (EPA 1997).

\subsubsection{Site Mobilization and Preparation Work}

Upon initiation of the project, mobilization will occur of personnel, procurement of consumables, and equipment required for the demolition. The first activities to be performed will be to locate fixed photographic locations that will be used to monitor the project progress on a minimum monthly basis, and to terminate and/or verify termination of all building services and utilities. These activities include isolation of electrical, sewer, and water to the facility. Concurrent with these activities, waste segregation and staging areas will be set up (within the area of contamination) to facilitate transportation of the material to its respective destination for recycling or disposal. A supervisor trailer, lunch trailer, change trailer, a MODEC trailer and portable toilet facilities will also be mobilized at the site in preparation for $D \& D$ activities. Electricity will be connected from an outside line and temporary lighting will be installed. Handrails will be installed where necessary for a safer work environment. 
Rev. 0

\subsubsection{Monitoring, Sampling and Analysis}

During and after demolition activities, field screening and sampling will be conducted to assure that hazardous and radiological wastes are removed in accordance with data obtained during assessment phase sampling. Confirmatory sampling will be conducted, during and after removal activities, in known areas where hazards were once present. Verification will meet the cleanup limits in Section 5.5, and a verification sampling analysis plan will be written to establish specific sampling criteria. The verification sampling and analysis plan will be submitted to the U.S. Environmental Protection Agency (EPA) for approval. Verification of belowgrade structures and soils will occur prior (as required and upon EPA approval) to any backfilling.

Details on monitoring activities are provided in Section 4.1, and sampling and analysis is discussed in more detail in Section 4.3.

\subsubsection{Decontamination and Decommissioning}

Work activities, in general, will start on the fourth floor/penthouse and work progressively downward towards the basement. The first type of work activity inside the building will be general housekeeping: removing unneeded tools, equipment, biological feces, rubble, sweeping floors, etc. After these activities are completed, removing gypsum wall and ceiling boards will commence while verifying that the material is radiologically clean. Removing all wall and ceiling boards will allow better access for the removal of asbestos-containing material (ACM). Additional personal protective equipment (PPE) may be required when removing drywall due to friable asbestos present next to the work being conducted as identified by the 108-F Facility health and safety plan (HASP) or asbestos abatement work plan (AAWP). ACM consists of insulation for piping, floor tiles, transite, joint compound, wall insulation, etc. For ACM removal, each level of the building will establish a negative-pressure enclosure. Asbestos work, air monitoring, and worker safety requirements will conform to existing Bechtel Hanford, Inc. (BHI) procedures for ACM removal and will be described in more detail in the AAWP.

All other hazardous substances (polychlorinated biphenyls [PCBs], mercury, and lead) will then be removed. Lead contained in a battery and sheeting in drywall; PCBs; oil from motors and light ballasts; and mercury found in lighting components and switches will be disposed of as hazardous waste or treated as recyclable material per Section 4.2.

Upon completion of removal of hazardous substances, final demolition activities will commence. Fixed radiological contamination, the pipe trench, and pipe trench sump will be covered to facilitate removal after demolition of most of the abovegrade structure. Any portion of the pipe trench, or any other material that is above cleanup standards (EPA 1997), will be removed before backfilling. The abovegrade structure will be brought down and steel will be segregated for salvage. Radiological material in the pipe trench will be removed and disposed at the Environmental Restoration Disposal Facility (ERDF) as low-level waste. Fixed contamination in the pipe trench and sump will be painted first with yellow as low as reasonably achievable (ALARA) paint, followed by a Radiological Control Technician survey, and a final coat of paint (any color other than yellow) will then be applied. Fixed 
DOE/RL-97-29

Rev. 0

radiological contamination will be removed using baseline heavy equipment machinery. Dust suppressants (water) will be used to control dust.

Abovegrade concrete will be demolished, segregated, and placed into an inert demolition waste landfill (e.g., the 183-F clearwell). During the demolition phase, additional interior piping and equipment not removed during the predemolition work will be exposed and removed. The belowgrade concrete and steel will be demolished in place to a depth of $0.91 \mathrm{~m}(3 \mathrm{ft})$ belowgrade and filled to eliminate future subsidence. Other nonrecyclable/nonhazardous debris will also be placed in an inert demolition waste landfill (as they are demolished) for disposal.

The liquid found in the bottle in the french drain was disposed of as mixed waste due to its presence of chromium and radionuclide content. The french drain, located on the east side of the building (exterior), will be removed and soil surrounding the drain will be removed until cleanup levels are attained. Cleanup standards for the project are discussed in more detail in Section 5.5. If cleanup of soils surrounding the french drain is too extensive to be managed in a cost-effective manner, then the site will be stabilized in a manner to not hinder future remediation. Future cleanup, if necessary, will occur at the same time as waste sites are addressed in the 100-FR-1 and 100-FR-2 OUs. The french drain is documented in the Waste Information Database as 100-F-15 and is located adjacent to the east wall of the 108-F Facility at approximate Hanford Site coordinates N79100, W30360.

\subsubsection{Disposal}

The 108-F Facility will have low-level radioactive wastes, mixed wastes, hazardous waste, recyclable materials, and solid wastes for disposal. The majority of the nonhazardous/nonrecyclable debris from the demolition of the building will be placed into an inert demolition waste landfill. The majority of the structural steel from the building will be segregated for salvage when radiologically cleared. Section 4.2 provides detailed disposal information.

\subsubsection{Site Restoration}

Upon completion of demolition activities, and if verification surveys of the site indicate that cleanup levels have been met, belowground void spaces will be backfilled with nonhazardous/nonrecyclable material. Approximately the top $0.6 \mathrm{~m}(2 \mathrm{ft})$ will be backfilled with soil containing no greater than $20 \%$ cobble to facilitate future revegetation of the site. The final grade of the site will be such that it is consistent with the surrounding terrain. If contamination is found during verification surveys, cleanup will proceed until it is determined not cost effective to continue. If this is the case, the site will be stabilized in a manner to not hinder future remediation.

\subsubsection{Demobilization}

After verification surveys have been completed and the site has been graded consistent with surrounding terrain, trailers, equipment, and personnel will be demobilized from the 108-F Facility. 
DOE/RL-97-29

Rev. 0

\subsubsection{Project Closeout}

After final completion of all demolition activities, a final project closeout report will be prepared; detailed information is provided in Section 5.5.

\subsubsection{Project Support}

Throughout the course of the project, oversight will be conducted by various project members to ensure compliance with ARARs and BHI procedures.

\subsection{FACILITY HAZARDS}

The following section is a summary of the 108-F Facility hazard classification document (Palmquist 1996) and characterization report (Harris 1996b).

Hazardous substances (mainly asbestos and lead) exist throughout the structure. Due to previous decontamination efforts, radiologic contamination exists in only small areas/quantities within the building. The project will perform hazardous substances remediation, followed by demolition down to the first level of the building. After fixed radiological material is removed on the first floor, demolition down to $0.91 \mathrm{~m}$ ( $3 \mathrm{ft}$ ) belowgrade will occur in accordance with the action memorandum (EPA 1997). The area will then be backfilled and graded to match the surrounding grade.

\subsubsection{Hazardous Substances}

The building contains mercury, PCBs, lead, and asbestos. Mercury exists in the fire alarms, switches, and possibly in the laboratory drains (based on previous D\&D experience). PCBs exist in the equipment oils and the light ballasts within the building. Lead exists in the form of $1 / 8$-in.-thick ( 0.80 $\mathrm{cm}$ ) sheets lining several walls, doors, and ceilings; one battery; lead-based paint; and lead joints in cast-iron pipes. ACM exists in the form of piping and equipment insulation, transite panels, transite pipe, floor tiles, and roof flashing.

Although lead and asbestos exceed the reportable quantities sited in 40 Code of Federal Regulations (CFR) 302, the potential for release of these materials is minimal because all lead and asbestos will be removed in accordance with approved procedures that assure control over hazardous substances. Environmental Restoration Contractor (ERC) standards and procedures for asbestos and lead on the Hanford Site are intended to ensure that personnel control, handling, and disposal of asbestos and lead materials are performed in a manner that achieves the following objectives:

- Protects the safety of employees and the general public

- Minimizes spills and releases to the environment 
Rev. 0

- Meets applicable U.S. Department of Energy (DOE), federal, state, and local regulatory requirements.

Some wastes may require treatment before final disposition; this is discussed in more detail in Section 4.2 .

A radiological contamination cleanup effort began in 1977 that removed contaminated materials and gloveboxes to support the facility $S \& M$ program. Currently, all radiological materials are far below the reportable quantities in 40 CFR 302.

\subsubsection{Facility Classification}

A facility classification, required for DOE facilities per DOE Order 5480.23 (DOE 1992), is an analysis of a facility that analyzes hazardous and radiological inventory. This inventory is analyzed to determine what is releasable; these levels are then compared to the reportable quantity levels listed in 40 CFR 302, Table 302.4 and its corresponding appendices. BHI-DE-01, Engineering Department Project Instruction, EDPI-4.28.01, "Hazard Classification," establishes the basis for classifying a facility and appropriate actions if a change in inventory is significant enough to change the facility classification or authorization basis.

Lead and asbestos are the only two hazardous substances that exceed the reportable quantity in 40 CFR 302. No adverse impact on employees, the general public, or the environment as a result of these activities is expected. This is due to the absence of hazardous substances that can be classified as "potentially releasable," since all lead and asbestos will be removed in accordance with approved procedures that assure control over hazardous substances.

Based upon the hazardous and radiological material inventories and the approved methods of removal, the hazards associated with these activities are classified as INDUSTRIAL. No additional safety analysis documentation is required.

\subsection{STRUCTURES, SYSTEMS, AND COMPONENTS THAT PROTECT FACILITY WORKERS}

Controls that will be employed during the 108-F Facility decommissioning process include temporary confinement enclosures, glovebag containments, and PPE as directed by the 108-F Facility HASP or AAWP for asbestos removal. Personnel and area monitoring, as required, will be used to determine and document work conditions and worker exposures.

Temporary confinement enclosures will be constructed to provide proper air-flow conditions and will be fabricated of noncombustible and fire-retardant materials. Glovebag enclosures will be essentially one-use protective measures used to prevent contamination release during specific operations (i.e., pipe cutting, sample collection, etc.). Glovebags are available in a variety of sizes and designs, or can be ordered to tailored specifications in accordance with intended use. 
DOE/RL-97-29

Rev. 0 
DOE/RL-97-29

Rev. 0

\subsection{SAFETY AND HEALTH MANAGEMENT AND CONTROLS}

\subsection{EMERGENCY PLANNING}

The ERC Emergency Management Program (preparedness, planning, and response) is described in detail in BHI-SH-03, Emergency Management Program which contains administrative responsibilities and emergency implementing procedures for compliance with the Hanford Emergency Response Plan (DOE/RL 1994), applicable DOE Orders, and state and federal regulations.

All emergency planning and preparedness activities for this project will be consistent with planning and preparedness actions with other Hanford Site contractors and relatively similar projects to ensure the health and safety of workers, the public, and protection of the environment in the event of an abnormal incident at the 108-F Facility.

\subsection{HEALTH AND SAFETY PROGRAM}

\subsubsection{Worker Safety Program}

The ERC Hazardous Waste Operations Safety and Health Program was developed for employees involved in hazardous waste site activities. The program was developed to comply with the requirements of the Occupational Safety and Health Administration 29 CFR 1910.120 and 10 CFR 835 , and to ensure the safety and health of workers during hazardous waste operations. The program includes the following elements:

- An organizational structure that specifies the structure of the organization, the official chain of command, and the overall responsibilities of supervisors and employees

- A comprehensive work plan developed before work begins at a site to identify operations and objectives, and to address the logistics and resources required to accomplish project goals

- A site-specific health and safety plan (SS HASP) where workers may be exposed to hazardous substances

- Worker training commensurate with their job duties and work assignments

- A medical surveillance program administered to comply with Occupational Safety and Health Administration, 29 CFR 1910.120 requirements

- BHI-SH-02, ERC Safety and Health Procedures, Volumes 1 through 4, along with project/ task-specific implementing plans and procedures 
DOE/RL-97-29

Rev. 0

- Volunteer Protection Plan.

\subsubsection{Site-Specific Health and Safety Plan}

A SS HASP will be prepared that defines the following:

- chemical

- radiological

- $\quad$ physical hazards

- controls and requirements for work site activities.

In addition to the SS HASP, a radiological work permit (RWP) will be prepared for work in areas with potential radiological hazards. The RWP extends the Radiological Protection Program to the specific work site or operation. All personnel assigned to the project and all work site visitors must strictly adhere to the SS HASP and RWP provisions. SS HASP elements include the following:

- Results of a risk and hazard analysis of each task and operation in the work plan

- List of employee training assignments

- List of PPE to be used by employees at the work site

- Medical surveillance requirements

- Frequency and type of air monitoring, environmental sampling techniques, and instrumentation to be used at the work site

- Worksite control measures

- Decontamination procedures

- Emergency response

- $\quad$ Confined-space entry procedures

- Spill containment program.

\subsubsection{ALARA Plans and Goals}

BHI-SH-02, Procedure 1.22, "Planning Radiological Work," outlines the planning process for performing radiological work and addresses appropriate work scope where an ALARA review is required. The D\&D work scheduled for the 108-F Facility will not have a comprehensive ALARA 
review performed; however, each work package will be reviewed and signed by the cognizant radiological engineer. If the scope of work (as defined in $\mathrm{BHI}-\mathrm{SH}-02$, Procedure 1.22) exceeds a radiological trigger level, the appropriate ALARA review will be performed.

\subsection{MAINTENANCE MANAGEMENT}

A letter of understanding has been transmitted between $S \& M$ and $D \& D$ to turn over possession and responsibility to $\mathrm{D} \& D$ projects. There are no systems to be maintained during decommissioning. Inspections, checks, and maintenance, which are activities normally conducted under S\&M, will not be conducted during the $\mathrm{D} \& \mathrm{D}$ process. Access control to the facility during $\mathrm{D} \& \mathrm{D}$ activities will be under the control of the responsible Field Superintendent for the 108-F D\&D Project (Figure 5). 
DOE/RL-97-29
Rev 0

Figure 5. Project Organization Chart for the 108-F Facility Project.
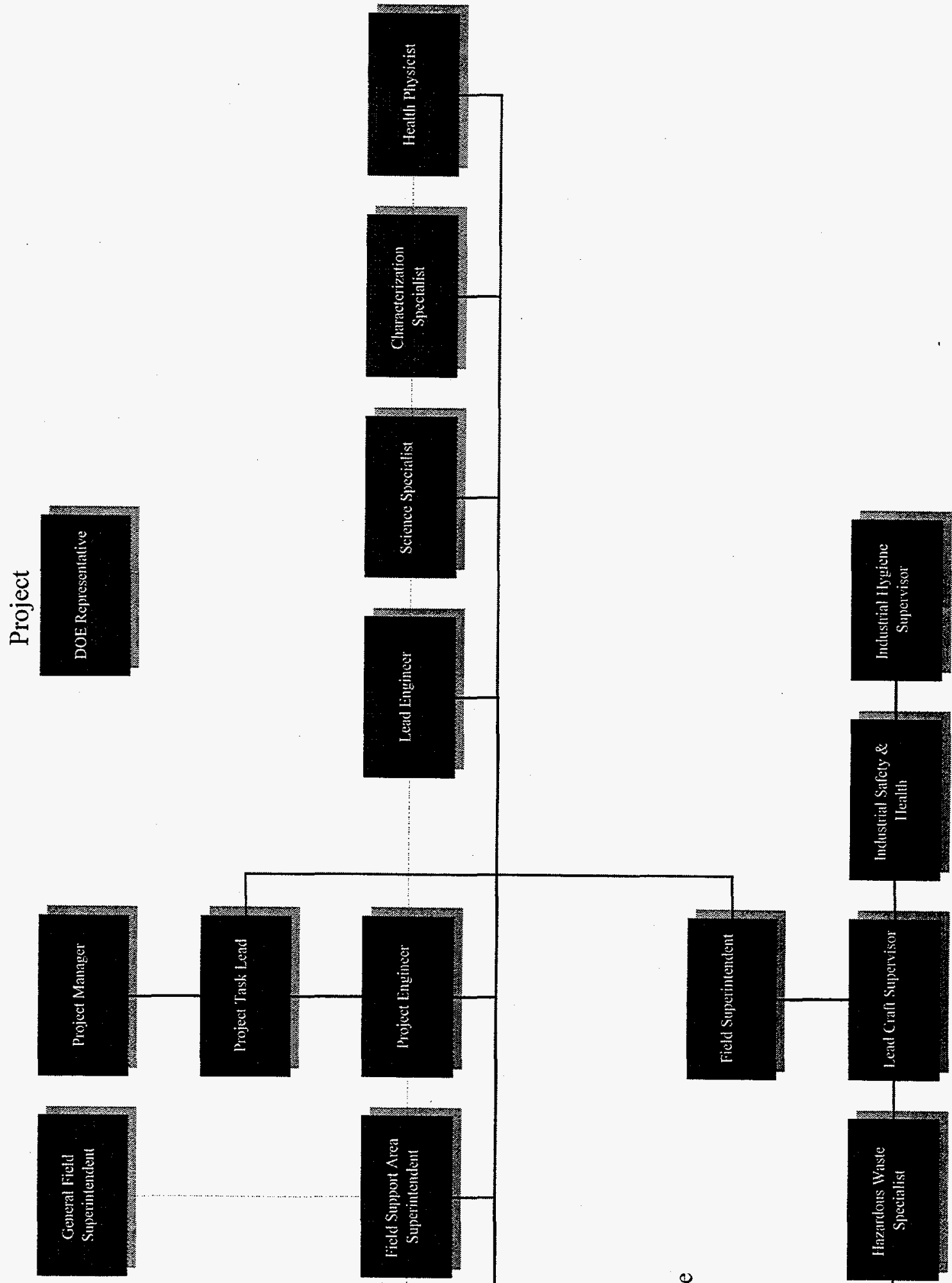

䲶

莺

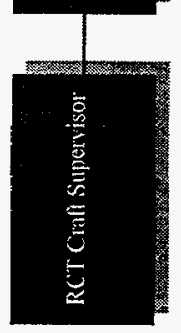


DOE/RL-97-29

Rev. 0

\subsection{ENVIRONMENTAL MANAGEMENT AND CONTROLS}

\subsection{APPLICABLE OR RELEVANT AND APPROPRIATE REQUIREMENTS}

The purpose of this section is to describe how each of the ARARs identified in the action memorandum (EPA 1997) will be met during the removal action.

The Safe Drinking Water Act, 40 CFR Section 300, as implemented by WAC 246-290, establishes maximum contaminant levels for public drinking water supplies. No residual contamination will be left behind after decommissioning of the 108-F Facility. All contaminated portions, mainly the pipe trench and french drain soils, will be removed thereby meeting maximum contaminant levels. Any surrounding soil that may be contaminated will be addressed in the final action for the OU.

Model Toxics Control Act (WAC 173-340) cleanup levels will be met in the structure remaining after demolition. Surrounding soil will be addressed in the final action for the OU.

The Clean Water Act of 1977, as implemented by WAC 173-201, establishes cleanup goals that address protection of the Columbia River. This removal action will have no discharges to surface waters and no residual contamination will remain after decommissioning of the facility. Therefore, protection of the Columbia River is provided through removal and disposal of all building contamination.

Removal of hazardous substances from the facility will be conducted in accordance with the waste generator requirements of Resource Conservation and Recovery Act of 1976, Subtitle C (40 CFR 262) as implemented by the State of Washington dangerous waste regulations (WAC 173-303), including waste designation, waste storage prior to disposal, and disposal restrictions. Waste disposal will also be governed by the requirements of Resource Conservation and Recovery Act of 1976 land disposal restriction (40 CFR 268); radiological waste land disposal requirements of 10 CFR 61, Subpart C; and the ERDF waste acceptance criteria (Roeck 1996) for onsite disposal.

Solid waste will be managed in accordance with WAC 173-304 with an emphasis on recycling or reuse to the maximum extent possible. This type of waste will primarily be disposed of at inert demolition waste landfills (clear wells) and offsite disposal at a municipal/industrial landfill.

The Toxic Substances Control Act of 1976 (40 CFR 761) regulates the management and disposal of PCBs and PCB waste. All waste suspected to contain PCBs will be evaluated to determine whether it meets the ERDF waste acceptance criteria (Roeck 1996). Any PCB waste that does not meet the ERDF waste acceptance criteria will be disposed offsite at a Toxic Substances Control Act of 1976-approved facility.

Removal and disposal of asbestos and ACM is regulated under the Clean Air Act of 1955 (40 CFR 61, Subpart M) and the Occupational Safety and Health Administration (29 CFR 1910.1101 and WAC 
296-62). These regulations provide special precautions to prevent exposure of workers to airborne emissions of asbestos fibers.

The Hazardous Materials Transportation Act of 1974 (49 U.S.C. 1801-1813), as implemented by the Department of Transportation requirements for transportation of hazardous substances (49 CFR 100 to 179), governs offsite shipment of hazardous substances. All offsite shipments for disposal will comply with these packaging, marking, labeling, and shipping requirements.

No wells will be installed or abandoned during this removal action. Thus, WAC 173-160 and WAC 173-162 do not apply.

The National Historic Preservation Act of 1966 (implementing regulation at 36 CFR 800) requires federal agencies to consider the effect of an activity on any significant cultural resource. The Archeological and Historical Preservation Act of 1974 requires action to recover and preserve artifacts in areas where activity may cause irreparable harm, loss, or destruction of significant artifacts. As part of site preparation activities, a cultural resource evaluation will be conducted to ensure that the demolition does not impact a significant cultural resource. It is unlikely that any archeological sites would be impacted by the demolition of the existing structure.

The Endangered Species Act of 1973 (implementing regulations of 50 CFR 402) and WAC 232-12-297 prohibit activities that threaten the continued existence of listed species or destroy critical habitat. Threatened and endangered species are known to be present in the 100 Area, but no adverse impacts on protected species or critical habitat is anticipated from the demolition activities. An ecological review will be conducted prior to demolition to identify any potential impacts.

The State of Washington Department of Health requirements for release of airborne radionuclides (WAC 246 and 247) will be met by air monitoring and the use of best available radionuclide control technology (BARCT). High efficiency particulate air filters will be mounted on machinery used for decontamination activities. Those portions of the facility that cannot be cleared through decontamination will use the BARCT to control emissions. For the 108-F Facility, BARCT has been identified as fixation using ALARA yellow paint and then a second coat of paint with a color other than yellow. Additionally, water will be used as a dust suppressant in all phases of construction.

Air monitoring requirements will be established based on calculations of radiological inventory. If National Emission Standards for Hazardous Air Pollutants compliance monitoring is required, it will be continuous monitoring using high efficiency particulate air filters. Otherwise, periodic confirmatory sampling will be used. This consists of grab sampling and/or continuous low volume sampling on the downwind side of the radiological work activities. The number of samplers will depend on the radiological risk of the work. At a minimum, one air sampler will be running during radiological work activities. When the work takes place inside the building, an air sampler will be located to ensure that no radiological air emissions are released outside of the work area in the building. 
Rev. 0

\subsubsection{Other Criteria, Advisories, or Guidance to Be Considered for this Action}

The action memorandum (EPA 1997) determined the appropriate cleanup level for radionuclides at 15 $\mathrm{mrem} / \mathrm{yr}$ based on the EPA Draft Proposed Rulemaking for Cleanup of Radionuclides in Soils to 15 mrem/yr above natural background and the Nuclear Regulatory Commission Draft Proposed Rulemaking for Cleanup of Radionuclides in Soils to $15 \mathrm{mrem} / \mathrm{yr}$ above natural background.

The ERDF waste acceptance criteria (Roeck 1996) includes contaminant concentration, waste form limitations, and other requirements for disposal of onsite waste at the ERDF. All waste intended for disposal at the ERDF will meet these requirements.

The radiation protection guidance recommends non-medical radiation doses to the general public from all sources and pathways not exceed $100 \mathrm{mrem} / \mathrm{yr}$ above background. The guidance also recommends that radiation doses from individual sources or pathways be lower. The removal action will meet a 15 mrem/yr goal, excluding surrounding soils.

The Revised Procedures for Planning and Implementing Off-site Response Actions (EPA 1987) describes procedures that should be observed when a response action under Comprehensive Environmental Response, Compensation, and Liability Act of 1980 (CERCLA) involves offsite storage, treatment, or disposal of CERCLA waste. The EPA Remedial Project Manager will be responsible for decisions regarding the offsite disposal of 108-F Facility waste.

\subsection{WASTE MANAGEMENT PLAN}

All activities will be performed in accordance with waste management ARARs identified in the action memorandum (EPA 1997).

All waste generated that has the potential to be regulated will be characterized and designated in accordance with BHI-EE-02, Environmental Requirements, Section 12.0, "Waste Management Program Requirements," and BHI-FS-03, Field Support Waste Management Requirements, and the requirements of the receiving facility. Specifically, wastes destined for the ERDF will be:

- Characterized in accordance with the characterization plan (Harris 1996a)

- Designated in accordance with the following:

- BHI-EE-02, Attachment 1, "Characterization and Designation"

- BHI-FS-03, Procedure W002, "Waste Certification"

- Environmental Restoration Disposal Facility Waste Acceptance Criteria (Roeck 1996).

Waste destined for one of the Project Hanford Management Contractor-controlled facilities will be designated and characterized in accordance with BHI-EE-02, Section 12 and Hanford Site Solid 
Waste Acceptance Criteria (WHC 1996). Sampling will be consistent with the characterization plan (Harris 1996a).

The transportation, packaging, handling, and labeling of waste will be addressed in a Site Specific Waste Management Instruction prepared in accordance with BHI-FS-03, Procedure W-006, "Site Specific Waste Management Instructions." The Site Specific Waste Management Instruction will address all aspects of waste handling as they specifically apply to anticipated waste streams at the 108-F Facility.

Disposal requirements will be met through compliance with Hanford Site Solid Waste Acceptance Criteria (WHC 1996) for wastes intended to be sent to Project Hanford Management Contractor facilities, and with ERDF waste acceptance criteria for wastes bound for ERDF (Roeck 1996).

Characterization activities for this facility have identified the following waste streams to date:

- Solid waste

- Low-level radioactive waste

- Mixed waste (waste that is both low-level radioactive waste and hazardous waste)

- Used oil

- Hazardous, dangerous, and PCB wastes.

Basic management strategies are discussed below; however, if other more cost-effective methods become available, they may be used. Throughout the project, material will be recycled whenever possible.

- Solid waste: Solid waste will be managed in accordance with WAC 173-304 with an emphasis on recycling or reuse to the maximum extent possible. This type of waste will primarily go to inert demolition waste landfills (clear wells such as the 183-F clearwell) and offsite disposal at a municipal/industrial landfill such as the city of Richland landfill.

- Low-level radioactive waste: Low-level radioactive waste that meets ERDF waste acceptance criteria will be disposed of at the ERDF.

For the 108-F Facility, the french drain and surrounding soils will be low-level waste. Most of the fixed radiological contamination in the pipe trench and pipe trench sump will also be low-level waste.

- Mixed waste: Mixed waste will be managed in compliance with the requirements for both hazardous/dangerous wastes (WAC 173-303) and radioactive waste (10 CFR 61). Due to the expected small size of mixed waste streams to be generated, waste will be shipped to the Central Waste Complex for long-term storage. If mixed waste streams are found in quantities large enough to make treatment a viable option, mixed wastes may be treated to meet applicable land disposal restrictions and disposed of at the ERDF. 
A 19-L (5-gal) carboy existed in the french drain that collected condensate from laboratory ductwork when in operation. Approximately $11.4 \mathrm{~L}$ ( 3 gal) of contaminated water existed in the bottle and was disposed of as mixed waste, due to the radiological and chromium constituents at the Central Waste Complex. Debris found in the pipe trench sump will be disposed as mixed waste due to the presence of lead and radioisotopes.

- Used oil: All used oil identified at this time is nonradioactively contaminated. The preferred management strategy is to manage the oil (except for PCB oils) as a recyclable material in accordance with the site-wide used oil program.

- Hazardous, dangerous, and PCB wastes: Hazardous wastes in the facility consist of mercury, lead, and PCBs. These wastes have been determined not to meet the ERDF waste acceptance criteria (above land disposal restrictions values). Some forms of mercury can be treated as a recyclable material if not radioactive. If any of these wastes are found to be radioactive, they will be treated as mixed waste. If not, they will be treated and disposed of at an approved EPA site and will meet the disposal site waste acceptance criteria of that particular disposal site.

\subsection{SAMPLING AND ANALYSIS PLAN}

Analytical assistance was used initially during 108-F Facility decommissioning to identify radiological and hazardous conditions that would be encountered in facility operations, and to specify the waste streams that would be generated. These technical services will also be used to characterize waste for disposal and to verify facility and area conditions at various phases of project completion. Analytical data generated in these efforts will be used to develop the following information:

- Contaminant identification

- Contaminant concentrations

- Waste type categories

- Worker health and safety conditions

- Decontamination requirements

- Operational precautions

- Waste treatment requirements

- Waste packaging and disposal requirements

- Volume.

Sample collection in support of these analytical studies will be performed at specific periods during decommissioning to provide current facility condition information and at random instances to develop knowledge of unanticipated findings. Sampling events will be performed throughout the duration of the decommissioning activities. It is desirable that sampling events be scheduled just prior to specific operations so the information developed is current to existing facility conditions. It is common for radiological conditions to change significantly during decommissioning operations. Planned analytical sampling will basically fall into one of the following categories. 
DOE/RL-97-29

Rev. 0

\subsubsection{Initial Characterization}

Initial characterization of the 108-F Facility started with a review of historical information, including the review of old procedures, technical manuals, drawings, photographs, and occurrence reports; interviews with retired personnel familiar with early Hanford Site operations; and review of radiological surveys and old waste disposal records. A walkthrough of the facility was conducted to visually identify potential sample points such as stains, leaks, low points in systems, and other potential collection points for contamination or hazardous substances. A draft characterization plan was then developed using information gained from the historical review and facility walkthrough. The draft plan was based on the guidelines for conducting scoping surveys and characterization surveys listed in A Manual for Conducting Radiological Surveys in Support of License Termination (NRC 1992) and in accordance with DOE Order 5400.5 (DOE 1993). Safety characterization and initial characterization guidelines are provided in the Decommissioning Handbook (DOE 1994). Analytical methods were based upon the guidelines in Test Methods for Evaluating Solid Waste (EPA 1986). The characterization report (Harris 1996b) along with the waste profiles were given to the regulators for review and are awaiting concurrence. This review will ensure that the data collected in Harris (1996b) will meet the requirements of WAC-173-303, Roeck (1996), and WHC (1996) for the waste designation at the 108-F Facility.

\subsubsection{In-Process Characterization}

The initial characterization plan collected information that was used for waste designation purposes. Some in-process sampling or nondestructive analysis may be necessary to ensure that the waste is properly designated as it is prepared for disposal. The in-process sampling/nondestructive analysis guidelines will be included in the routine work procedures for waste management and packaging. Sampling will be consistent with the characterization plan for the 108-F Facility (Harris 1996a).

Field screening and/or sampling will be conducted, but are not limited to, the following specific areas of concern:

- French drain soils: The initial characterization soil sample results showed that radiological contamination was present. Field screening followed by sampling will be conducted to verify that cleanup limits (Section 5.5) are met.

- Pipe trench: As stated in the characterization report (Harris 1996b), the pipe trench and pipe trench sump were found to contain fixed radiological contamination. In the pipe trench sump, loose debris was found to be the source of radiological contamination and chromium. The debris in the pipe trench sump will need to be disposed as mixed waste. Additional samples may be taken of the pipe trench and sump to designate the waste.

\subsubsection{Final Status Characterization}

A final status characterization will be performed to determine the final condition of the facility/site after D\&D activities are complete. This sampling and analysis effort will provide data to demonstrate 
that all residual radioactivity and hazardous or toxic materials meet the site cleanup criteria, as discussed in Section 5.5. A higher degree of assurance is needed when showing that the cleanup criteria have been met. The final status sampling and analysis plan will be developed based on the final release criteria; guidelines for conducting remediation control surveys; final status surveys described in Nuclear Regulatory Commission (1992) and in accordance with DOE Order 5400.5 (DOE 1993); characterization for material disposition guidelines described in the Decommissioning Handbook (DOE 1994); and the data quality objective process.

Although the final status characterization plan is discussed as if it were an activity performed at a single specified stage of the decommissioning process, this may not be the case. Data from sampling efforts conducted at other stages of the decommissioning, such as initial characterization, may be incorporated into the final status characterization when appropriate. The verification sampling analysis plan will be submitted to the EPA for approval.

\subsection{MITIGATION ACTION PLAN}

Most of the area surrounding the 108-F Facility is covered with asphalt and graveled surfaces. No native vegetation exists on the site and therefore no avoidance mitigation will be required to protect native plants. At the north end of the building and near the entrance gate are some juniper trees and shrubs that were planted as landscaping during the occupancy of the building. An effort will be made to preserve these plants as nesting and perching habitat to the extent practicable during demolition. Some of the plants are growing in immediate contact with the 108-F Facility and may be lost during demolition activities. An ecological review of the building was conducted in November 1996 to identify ecological resources (Brandt 1996). The findings of this review indicated that bats use the building during the summer months; as evidenced by the presence of bat feces and one dead pallid bat (a Washington State Monitor-2 species). The review concluded that no adverse impacts would occur to bats if demolition takes place outside their active season which is approximately April through October. If demolition is scheduled during their active season, a new ecological review will be conducted.

The 108-F Facility is adjacent to the 105-F Reactor Building exclusion fence. The area surrounding the 108-F Facility may be impacted during the stabilization effort planned for the 105-F Reactor Building and the remedial action projects planned for the associated waste sites. Therefore, revegetation of the 108-F Facility site is not planned to immediately follow demolition. However, provisions will be made during final site grading to ensure suitable soils are in place to facilitate revegetation at a later time to coincide with the 100-F Area remedial action projects.

A cultural resource review (Teel 1996) was also conducted in November 1996 that considered cultural as well as historic significance. The review concluded that the 108-F Facility is situated in an area of low cultural resource sensitivity and that no archeological resources have been recorded within or adjacent to the area of potential effect. Due to the extensive disturbance to the area, no intact subsurface materials are anticipated. Due to potential interest from Native American Tribal 
Rev. 0

representatives to monitor ground-disturbing activities associated with demolition, notification will be provided 1 week prior to ground-disturbing activities.

The review of the historic significance found that the 108-F Facility was determined by DOE, Richland Operations Office and the Washington State Historic Preservation Office (SHPO) to be a contributing property within the Hanford Site Manhattan Project/Cold War Era Historic District. Pursuant to stipulation IV (D) of the Historic Buildings Programmatic Agreement, SHPO must be notified that demolition of this property is scheduled and that the mitigation requirements prescribed under the Programmatic Agreement will be taken.

Mitigation for the 108-F Facility consists of the following:

- Preparation of an Expanded Historic Property Inventory Form (Appendix C, Table 1)

- Interior walk down by cultural staff to identify any artifacts which may have interpretive or educational value (Stipulation V [C]).

Concurrence from the SHPO is not required prior to demolition; project actions and cultural mitigation may proceed independently. The inventory form has been prepared and the internal walkdown has occurred. 
DOE/RL-97-29

Rev. 0

\subsection{PROJECT MANAGEMENT AND ORGANIZATION}

Project organization, training, and qualification needed for effective project achievement are discussed in this section. A readiness review will be conducted, in accordance with BHI-MA-02, ERC Project Procedures, Section 8.2, "Readiness Assessments," to detail the level of readiness that will be required to initiate project activities and the operational attitude that will be maintained throughout the project efforts. Further discussions will detail the responsibilities of quality management and will demonstrate how both project and facility condition changes will be controlled. The planned sequence of operations required to complete this project will be reflected on a project schedule, along with estimates of the associated costs. References to controlling documents and regulatory guidance will be included where appropriate. Figure 5 shows the project organization chart for the 108-F Facility Project.

\subsection{PROJECT SCHEDULE AND COST ESTIMATE}

Cost and resources for the 108-F D\&D Project (as presented in Appendix B) have been developed to include activity logic, manpower, equipment requirements, and schedule costs accordingly. The schedule in Appendix A is broken into several sections, most of which are natural performance measurement categories:

- Site mobilization and work preparation

- Monitoring, sampling, and analysis

- D\&D

- Disposal

- Site restoration

- Demobilization

- $\quad$ Project closeout

- $\quad$ Project support.

While these major categories of effort include many subcategory events, only minor changes in their scheduled performance can be experienced without affecting the accomplishment of project goals. Additional major efforts are involved in the project such as engineering evaluations, project management, waste assaying, and waste processing that is continuous throughout the project.

\subsubsection{Project Cost and Schedule Tracking}

This section establishes the administrative controls for tracking costs and schedules, identifies requirements for project reports, defines the work breakdown structure, and discusses the systems used for performance measurement and change control. Performance measurement and analysis will be performed by the D\&D Planning and Controls organization. Project cost and schedule will be controlled and updated using the ERC Management Control System, as described in ER-PC-01, Baseline and Funds Management System. 
This earned-value system tracks cost, schedule, and performance for all D\&D projects as they progress towards completion. Cost performance reports compare budgeted cost of work scheduled and budgeted cost of work performed to the actual cost of work performed. These reports provide information on variations from the baseline schedule and cost. Variations above threshold values are documented, along with reasons for the variance(s), and any recover plans required.

Changes (including changes in scope) are processed per ER-PC-01, Procedure PCP 1.12, "Change Control," which also maintains cost and schedule baselines for the project.

\subsection{CONDUCT OF OPERATIONS}

Conduct of operations is imposed to ensure that work is performed in a controlled and organized manner; that all facets of work activities have been considered; and that necessary documentation is maintained.

The performance of field activities in the 108-F Facility D\&D Project will be governed by Decontamination and Decommissioning Project Manager's Implementing Instructions (PMII) (BHI 1996) and applicable field support instructions and specific work instructions. The PMII are based on a graded approach to the Conduct of Operations authorized by DOE Order 5480.19 (DOE 1990) and the ERC N-Area conduct of operations applicability matrix. The PMII are applicable to all ERC personnel, assigned or matrixed, who perform activities under the responsibility and direction of the project manager. The applicability matrix is issued and maintained by the project manager and identifies elements of the DOE order that apply to project activities, the implementing documents, and any deviations or exceptions to the DOE Order guidelines.

Conduct of operations strongly emphasizes technical competency, workplace discipline, and personal accountability to ensure the achievement of a high level of performance during all activities. Project personnel are responsible for fully complying with the PMII and, if conflict arises with other instructions or directions, work shall be safely stopped until resolution is achieved. Safety is the number one priority, and all planning shall include appropriate safety analyses to identify potential safety and health risks and the means to appropriately mitigate them. Workers will not start work until approved safety procedures, instructions, and directions are provided for abnormal operations.

Conduct of operations requires workers to be alert and aware of conditions affecting the job site. Operators and workers conducting D\&D field activities should be notified of changes in the facility and/or work area status, abnormalities, and difficulties encountered in performing project operations. Similarly, operators and workers shall notify the chain of command of any unexpected situations. In accordance with the severity of a finding (i.e., emergency condition), notification requirements will be expanded to include upper-tier management and regulatory agencies. 
DOE/RL-97-29

Rev. 0

\subsection{REMOVAL ACTION CHANGE MANAGEMENT}

If a change arises that results in a fundamental change to the selected response action that is not within the scope of the action memorandum (EPA 1997) and the implementing documents, then an Engineering Evaluation/Cost Analysis or proposed plan and supporting documentation will be prepared to allow DOE, EPA, and the Washington State Department of Ecology to select a revised response action.

Changes and potential discoveries in hazardous or radiological inventory will be reviewed against BHI-DE-01, EDPI 4.28 and the RDR for the 108-F Facility.

\subsection{PERSONNEL TRAINING AND QUALIFICATIONS}

During the performance of project activities, the experience and capabilities of the operating staff are extremely important in maintaining worker and environmental safety. Decommissioning of the 108-F Facility will require the employment of workers dedicated to the project for the duration of the radiological efforts. Day-to-day knowledge of ongoing operations, month-to-month understanding of conditions encountered, and lessons learned will be vital to the continuance of safe operations.

Training requirements will ensure that personnel have been instructed in the technologies to work safely in and around radiological areas, and to maintain their individual radiation exposure and the radiation exposures of others ALARA. Standardized core courses and training material will be presented and site-specific information and technologies will be added to adequately train workers.

Health physics workers are required to have completed and be current in Radiological Control Technician qualification training. These training courses require the successful completion of examinations to demonstrate understanding of theoretical and classroom material.

Specialized training will be provided as needed to instruct workers in the use of nonstandard equipment, in the performance of abnormal operations, and in the hazards of specific activities. Specialized training may be provided by on-the-job training activities, by classroom instruction and testing, or by pre-job briefings. The depth of training in any discipline will be commensurate with the degree of hazard involved and the knowledge required for task performance.

Some activities associated with the 108-F Facility decommissioning will require the acquisition of expert services as opposed to project staff training. The assaying of waste packages and dismantling the facility by specialized methods are examples of activities requiring expert assistance.

The ERC Team Environmental Safety and Health Training Program provides workers with the knowledge and skills necessary to safely execute assigned duties. A graded approach is used to ensure that workers receive a level of training commensurate with their responsibility that complies with applicable requirements. Specialized employee training includes pre-job safety briefings, plans 
of the day, and facility/work site orientations. The following training and qualifications may be applicable as required by job assignment for 108-F Facility work activities:

Training in accordance with 29 CFR 1910.120:

- 40-Hour Hazardous Waste Worker/8-hour refresher

- 24-Hour Experience Component

- $\quad$ 8-Hour Supervisor Training (for selected individuals)

- $\quad$ SS HASP and RWP

- Respirator Training

- $\quad$ First aid (two qualified persons per shift/crew)

- Certified Asbestos Worker and/or Asbestos Awareness

- Lead Worker

- $\quad$ Radiation Worker II.

Medical surveillance requirements:

- Hazardous waste worker physical

- Mask fit

- Lead worker baseline

- $\quad$ Asbestos worker.

Dosimetry and bioassay requirements:

- Thermoluminescent dosimeter (as directed in the RWP)

- Whole body count.

\subsection{PROJECT CLOSEOUT}

After completion of all demolition activities, a final project closeout report will be prepared. The report will include the location and quantities of waste dispositioned, project costs, lessons learned, and a reconciliation to the conceptual model for $D \& D$ baseline estimating. The report will be forwarded to the records retention center where it will be included with the administrative record for the $100-\mathrm{F}$ OU.

Removal of the 108-F Facility and its systems will be completed to a depth of $0.91 \mathrm{~m}$ ( $3 \mathrm{ft}$ ) belowgrade. At this excavation level, radiological surveys and soil characterization will be conducted to verify the status of the terrain beneath and around the prior facility footprint. If the remaining soil is found to exceed the $15 \mathrm{mrem}$ per year radiological standard or the hazardous substance soil cleanup levels provided in WAC 173-340-745, a cap of clean borrow soil will be placed over the involved area, and routine $S \& M$ activities will be initiated. The S\&M efforts and remediation planning will be consistent with that established for the 100 Area. If contamination exceeding these criteria is left in 
place at the end of this removal action, the site will be identified for further remediation in conjunction with 100-FR-1 source site remedial actions.

The ARARs for the 108-F Facility D\&D Project activities identified in the action memorandum (EPA 1997) establish the cleanup criteria for the 108-F site. For soils, Model Toxic Control Act (Method B) soil cleanup levels specified in WAC 173-340 are the standards that must be met. The Model Toxic Control Act standards cannot be applied to structures unless they are belowgrade. Rubble created from the demolition of the structure will be evaluated against dangerous waste criteria, ERDF waste acceptance criteria (Roeck 1996), and radiological standards. Materials that exceed dangerous waste criteria radiological standards or WAC 173-304-100 inert waste standards will be appropriately segregated and disposed in accordance with Section 4.2. Subsurface structures and debris that meet the $15 \mathrm{mrem}$ and inert waste standards may be left in place.

The proposed radiation cleanup standard, as described in (40 CFR 196), would limit radiation doses to $15 \mathrm{mrem} / \mathrm{yr}$ above natural background. Limiting exposure levels to $15 \mathrm{mrem} / \mathrm{yr}$ above background acknowledges that background varies from site to site. Determining when D\&D has achieved the $15-\mathrm{mrem} / \mathrm{yr}$ cleanup level involves converting radionuclide concentrations (in $\mathrm{pCi} / \mathrm{g}$ ) in soil into dose rates (in mrem/yr) using a dose assessment model.

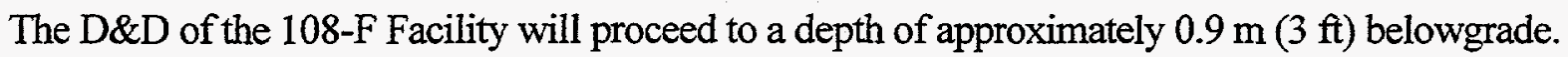
Remediation of soils or structures below a depth of $0.91 \mathrm{~m}(3 \mathrm{ft}$ ) that exceed the 108-F Facility cleanup criteria will be coordinated with associated $O U$ remedial action activities.

In accordance with 40 CFR 300.165, "National Contingency Plan," the on-scene coordinator will submit a complete report on the removal operation and actions taken to the Regional Response Team. This report must be submitted within 1 year after completion of removal activities. A copy of the report must also be directed to the Secretary of the National Response Team.

The report shall record the purpose for the removal action, the actions taken, the resources committed, and any problems encountered. The report must follow the format and contain information required in 40 CFR 300.165 . 
DOE/RL-97-29

Rev. 0 
DOE/RL-97-29

Rev. 0

\subsection{REFERENCES}

Archeological and Historic Preservation Act of 1974, 16 U.S.C. 469 et seq.

BHI, 1996, Decontamination and Decommissioning Project Manager's Implementing Instructions, BHI-00894, Rev. 0, Bechtel Hanford, Inc., Richland, Washington.

BHI-DE-01, Design Engineering Procedures Manual, EDPI-4.28.01, "Hazard Classification," Bechtel Hanford, Inc., Richland, Washington.

BHI-EE-02, Environmental Requirements, Bechtel Hanford, Inc., Richland, Washington.

BHI-FS-03, Field Support Waste Management Requirements, Bechtel Hanford, Inc., Richland, Washington.

BHI-MA-02, ERC Project Procedures, Bechtel Hanford, Inc. Richland, Washington.

BHI-SH-02, Safety and Health Procedures, Volumes 1 through 4, Bechtel Hanford, Inc., Richland, Washington.

BHI-SH-03, Emergency Management Program, Bechtel Hanford, Inc., Richland, Washington.

Brandt, C. A., 1996, Biological Review of the Demolition of the 108-F Biological Lab, 100-F Area, (external letter 97-100-002 to C. A. Palmquist, Bechtel Hanford, Inc.), Pacific Northwest National Laboratory, Richland, Washington.

10 CFR 61, "Licensing Requirements for Land Disposal of Radioactive Waste," Code of Federal Regulations, as amended.

10 CFR 835, "Occupational Radiation Protection," Code of Federal Regulations, as amended.

29 CFR 1910.120, "Hazardous Waste Operations and Emergency Response," Code of Federal Regulations, as amended.

36 CFR 800, "Protection of Historic and Cultural Properties," Code of Federal Regulations, as amended.

40 CFR 61, "National Emission Standards for Hazardous Air Pollutants," Code of Federal Regulations, as amended.

40 CFR 196, "Radiation Site Cleanup Regulation," Code of Federal Regulations, as amended.

40 CFR 262, "Generator Requirements," Code of Federal Regulations, as amended. 
DOE/RL-97-29

Rev. 0

40 CFR 268, "Land Disposal Restrictions," Code of Federal Regulations, as amended.

40 CFR 300, "National Contingency Plan," Code of Federal Regulations, as amended.

40 CFR 302, "Designation, Reportable Quantities and Notification," Code of Federal Regulations, as amended.

40 CFR 761, "Polychlorinated Biphenyls (PCBs) Manufacturing, Processing, Distribution in Commerce, and Use Prohibitions," Code of Federal Regulations, as amended.

50 CFR 402, "Interagency Cooperation -- Endangered Species Act of 1973," Code of Federal Regulations, as amended.

Clean Air Act of 1955, 42 U.S.C. 7401 et seq.

Clean Water Act of 1977, 33 U.S.C. 1251 et seq.

Comprehensive Environmental Response, Compensation, and Liability Act of 1980, 42 U.S.C 9601 et seq.

DOE, 1990, Conduct of Operations for DOE Facilities, DOE Order 5480.19, U.S. Department of Energy, Washington, D.C.

DOE, 1992, Nuclear Safety Analysis Reports, DOE Order 5480.23, U.S. Department of Energy, Washington, D.C.

DOE, 1993, Radiation Protection of the Public and Environment, DOE Order 5400.5, U.S. Department of Energy, Washington, D.C.

DOE, 1994, Decommissioning Handbook, DOE/EM-0142P, U.S. Department of Energy, Washington, D.C.

DOE-RL, 1994, Hanford Emergency Response Plan, DOE/RL-94-02, Rev. 0 (as amended), U.S. Department of Energy, Richland Operations Office, Richland, Washington.

DOE-RL, 1996, Engineering Evaluation/Cost Analysis for the 100-B/C Area Ancillary Facilities at the 108-F Building, DOE/RL-96-85, Rev. 0, U.S. Department of Energy, Richland Operations Office, Richland, Washington.

Ecology, EPA, and DOE, 1990, Hanford Federal Facility Agreement and Consent Order (Tri-Party Agreement), 2 vols, as amended, Washington State Department of Ecology, U.S. Environmental Protection Agency, and U.S. Department of Energy, Olympia, Washington. 
Endangered Species Act of 1973, Public Laws 93-205 through 100-707, 16 U.S.C. 1531 et seq.

EPA, 1986, Test Methods for Evaluating Solid Waste: Physical/Chemical Methods, SW-846, 3rd edition, as amended, U.S. Environmental Protection Agency, Washington, D.C.

EPA, 1987, Revised Procedures for Planning and Implementing Off-site Response Actions, OSWER Directive 9834.11, Office of Solid Waste and Emergency Response, U.S. Environmental Protection Agency, Washington, D.C.

EPA, 1997, Approved Action Memorandum for the $100 \mathrm{~B} / \mathrm{C}$ Area Ancillary Facilities and the 108-F Building Removal Action (external letter 042276 to J. M. Bruggeman, U.S. Department of Energy, Richland Operations Office), U.S. Environmental Protection Agency, Richland, Washington.

ER-PC-01, Baseline and Funds Management System, Bechtel Hanford, Inc., Richland, Washington.

Harris, R. A., 1996a, Characterization Plan for the 108-F Biological Laboratory, BHI-00829, Rev. 0, Bechtel Hanford, Inc., Richland, Washington.

Harris, R. A., 1996b, Final Characterization Report for the 108-F Biological Laboratory, BHI-00838, Rev. 0, Bechtel Hanford, Inc. Richland, Washington.

Hazardous Materials Transportation Act of 1974, 49 U.S.C. 1801-1813 et seq.

National Historic Preservation Act of 1966, 16 U.S.C. 470 et seq.

NRC, 1992, A Manual for Conducting Radiological Surveys in Support of License Termination, NUREG/CR-5849, U.S. Nuclear Regulatory Commission, Washington, D.C.

Palmquist, C. A., 1996, Preliminary Hazard Classification for the 108-F Building in Hanford's 100-F Area, (Interoffice Memorandum CCN 039206 to P. K. Jackson), Bechtel Hanford, Inc., Richland, Washington.

Resource Conservation and Recovery Act of 1976, 42 U.S.C. 6901 et seq.

Roeck, F. V., 1996, Environmental Restoration Disposal Facility Waste Acceptance Criteria, BHI-00139, Rev. 2, Bechtel Hanford, Inc., Richland, Washington.

Safe Drinking Water Act of 1974, 42 U.S.C. 300 f et seq.

Teel, D. D., 1996, Cultural Resources Review - 108-F Biological Lab Hazardous Material Remediation and Demolition (HCRC\# 95-100-045a) (external letter CCN 039111 to C. A. Palmquist, November 22), Bechtel Hanford, Inc., Richland, Washington. 
DOE/RL-97-29

Rev. 0

Toxic Substances Control Act of 1976, 15 U.S.C. 2601 et seq.

WAC 173-160, "Minimum Standards for Construction and Maintenance of Wells," Washington Administrative Code, as amended.

WAC 173-162, "Regulation and Licensing of Well Contractors and Operators," Washington Administrative Code, as amended.

WAC 173-200 through -216, "Water Quality Standards of the State of Washington," Washington Administrative Code, as amended.

WAC 173-303, "Dangerous Waste Regulations," Washington Administrative Code, as amended.

WAC 173-304, "Minimum Functional Standards for Solid Waste Handling," Washington Administrative Code, as amended.

WAC 173-304-100, "Definitions," Washington Administrative Code, as amended.

WAC 173-340, "Department of Ecology," Washington Administrative Code, as amended.

WAC 232-12-297, "Endangered, Threatened, and Sensitive Wildlife Species Classification," Washington Administrative Code, as amended.

WAC 246, "Department of Health," Washington Administrative Code, as amended.

WAC 246-290, "Public Water Supplies," Washington Administrative Code, as amended.

WAC 247, "Health Care Facilities Authority," Washington Administrative Code, as amended.

WAC 296-62, "Occupational Health Standards - Safety Standards for Carcinogens," Washington Administrative Code, as amended.

WHC, 1996, Hanford Site Solid Waste Acceptance Criteria, WHC-EP-0063, Rev. 4, Westinghouse Hanford Company, Richland, Washington. 
DOE/RL-97-29

Rev. 0

APPENDIX A

108-F DECONTAMINATION AND DECOMMISSIONING PROJECT SCHEDULE*

*Assumes field start date of October 1, 1997 
DOE/RL-97-29

Rev. 0

A-ii 


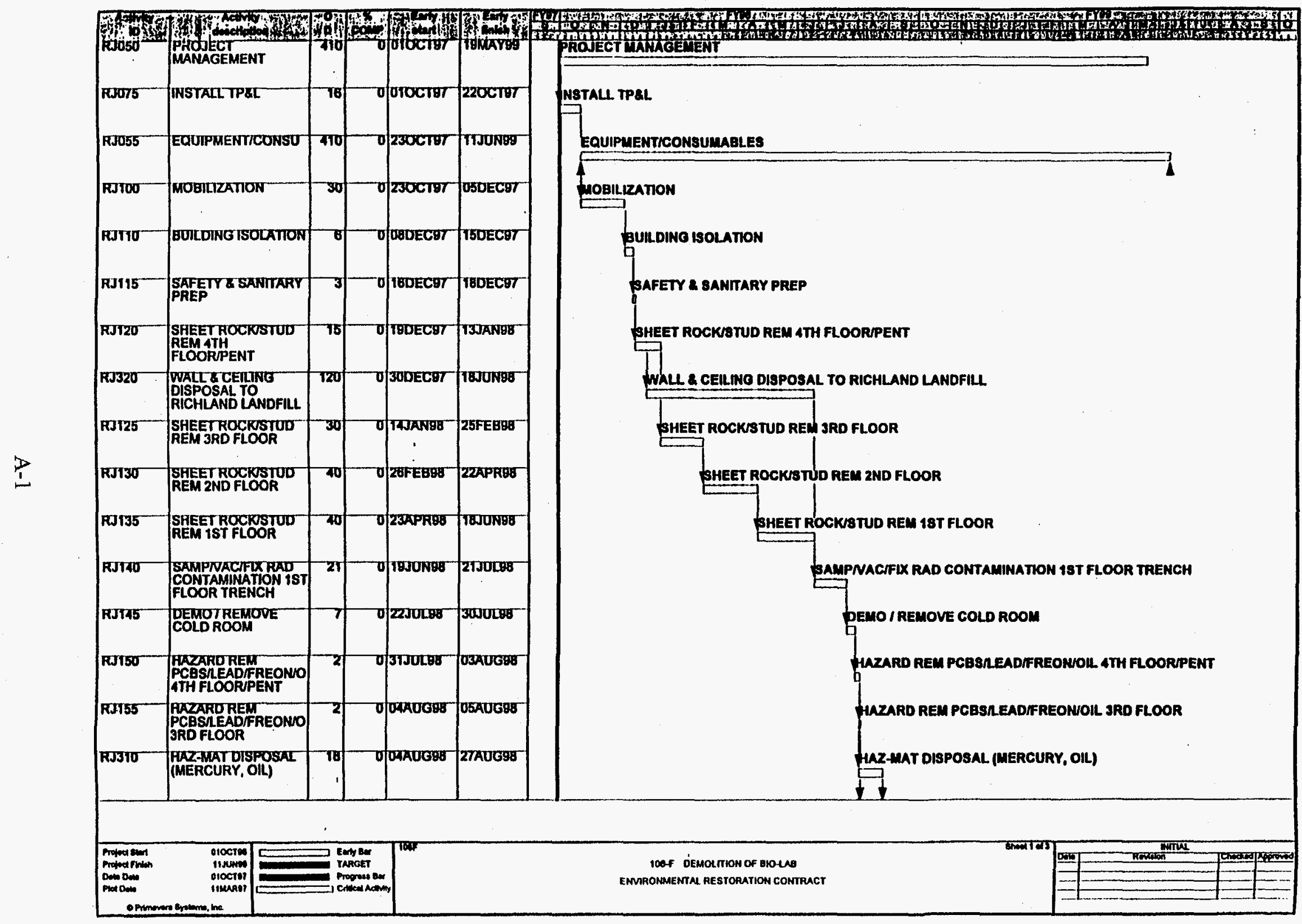




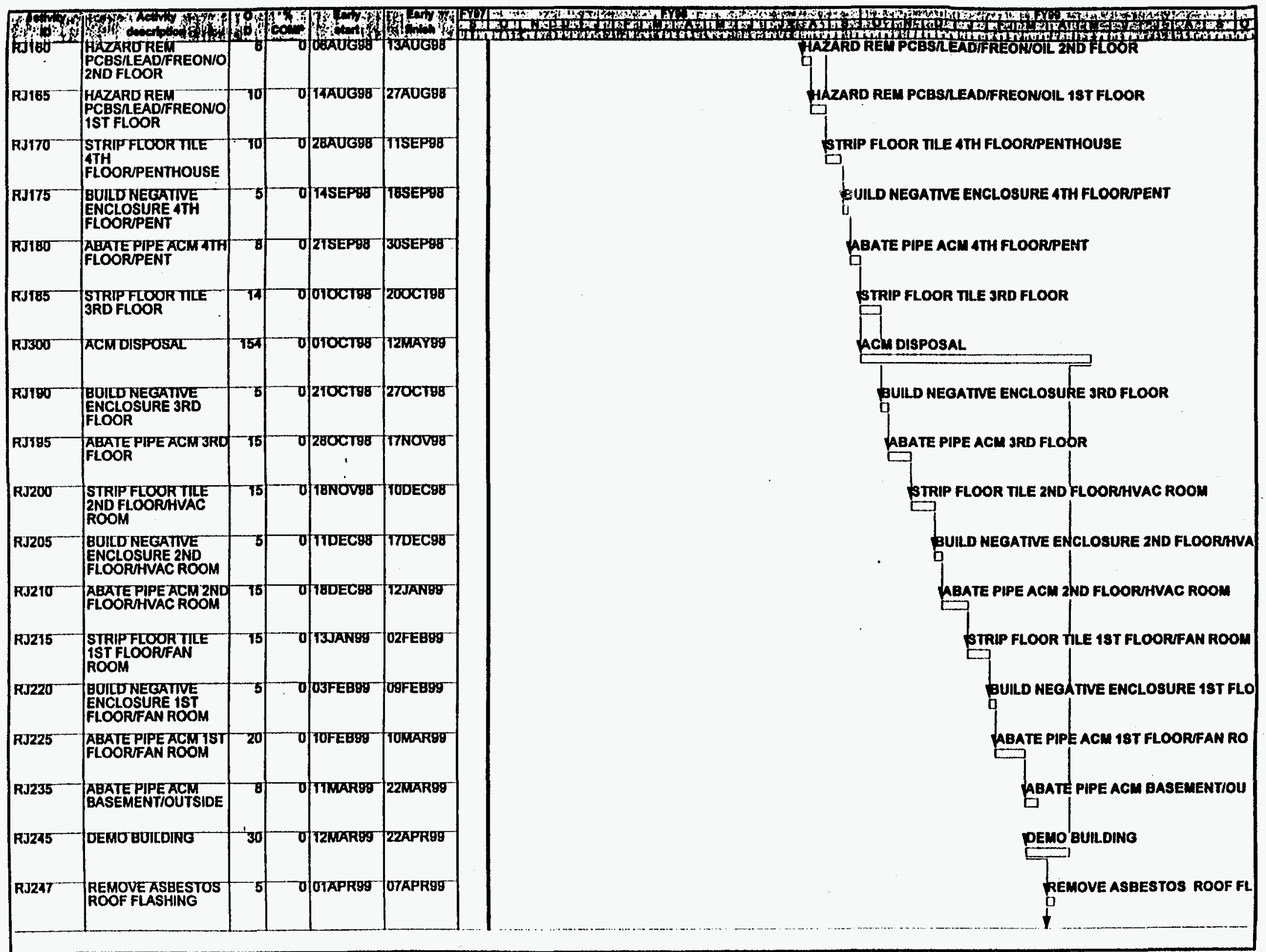


DOE/RL-97-29

Rev. 0

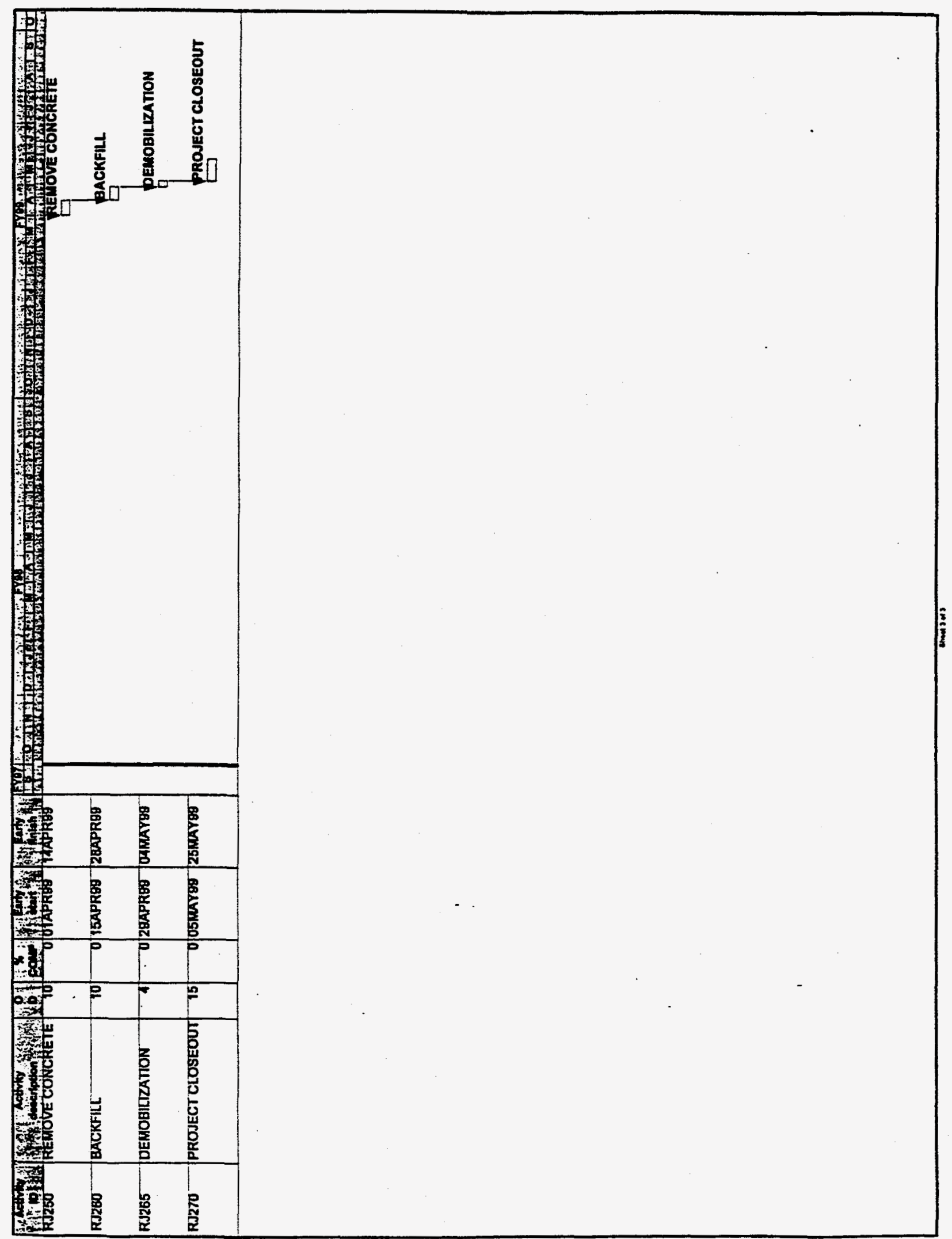

A-3 
DOE/RL-97-29

Rev. 0

A-4 
DOE/RL-97-29

Rev. 0

APPENDIX B

COST AND RESOURCES

B-i 
DOE/RL-97-29

Rev. 0

B-ii 


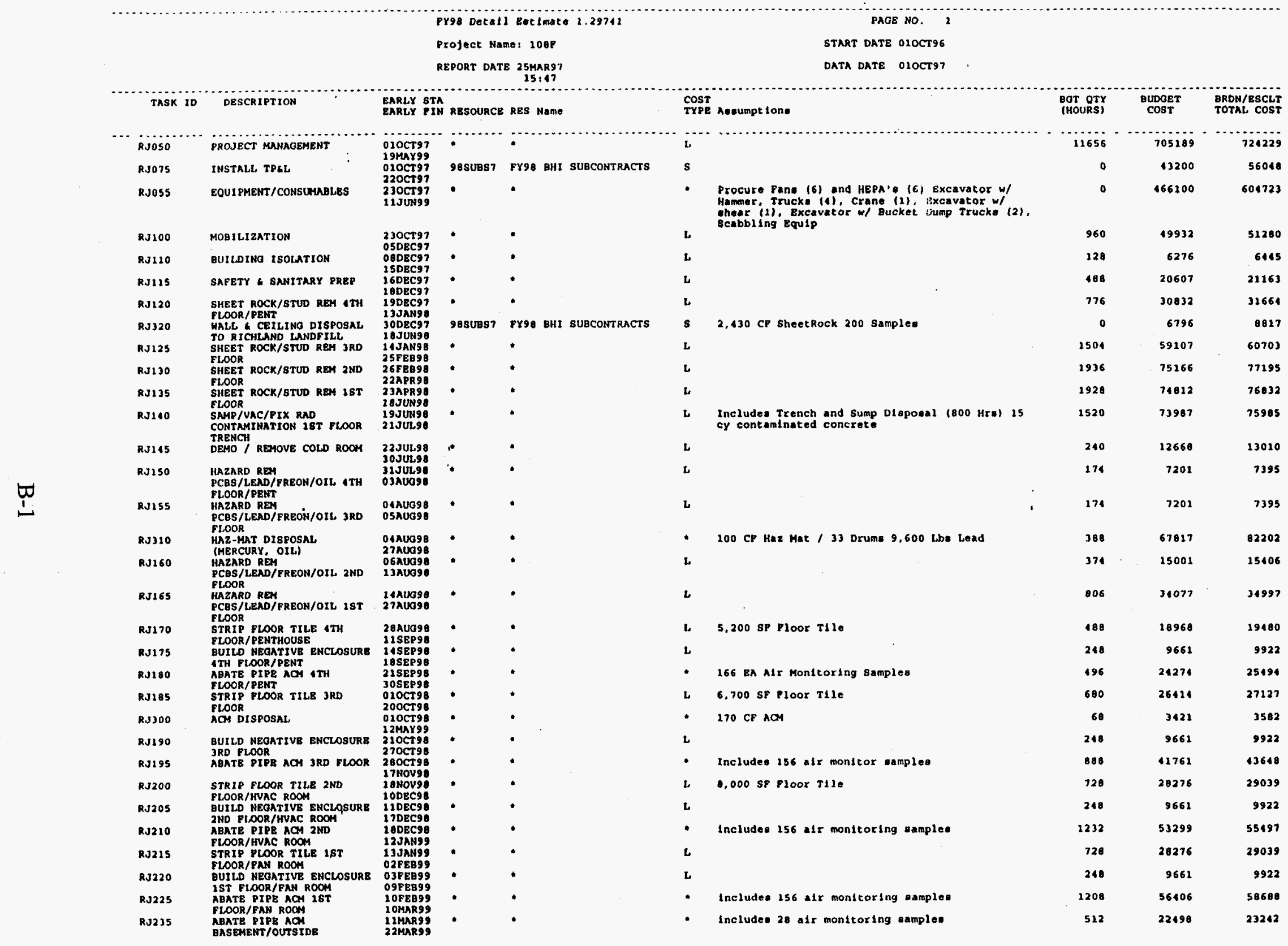




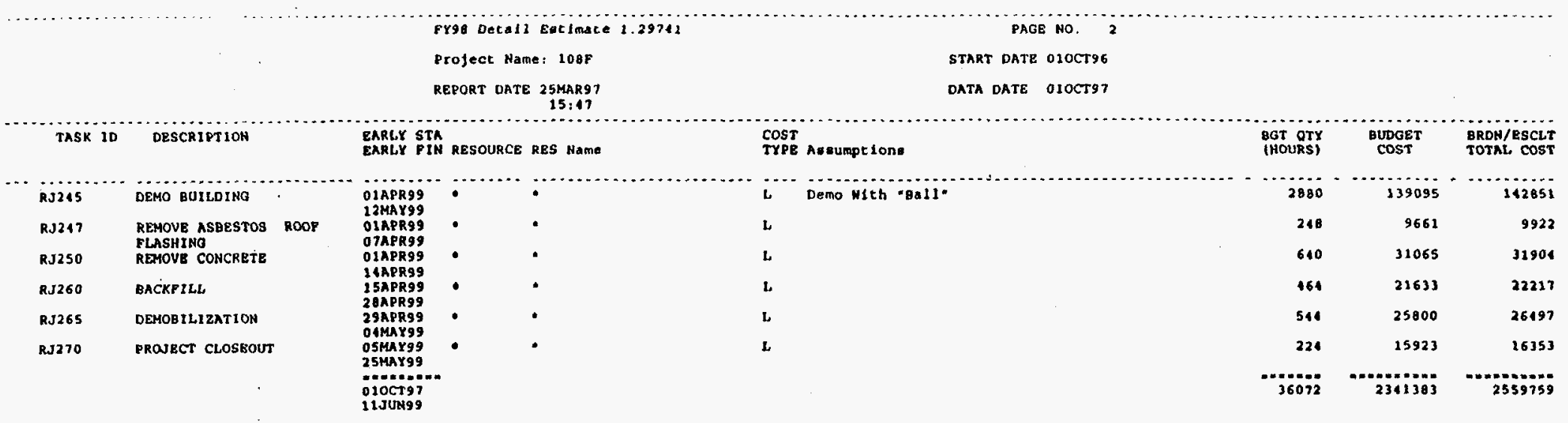


TOTAL NON-MANUAL RESOURCES

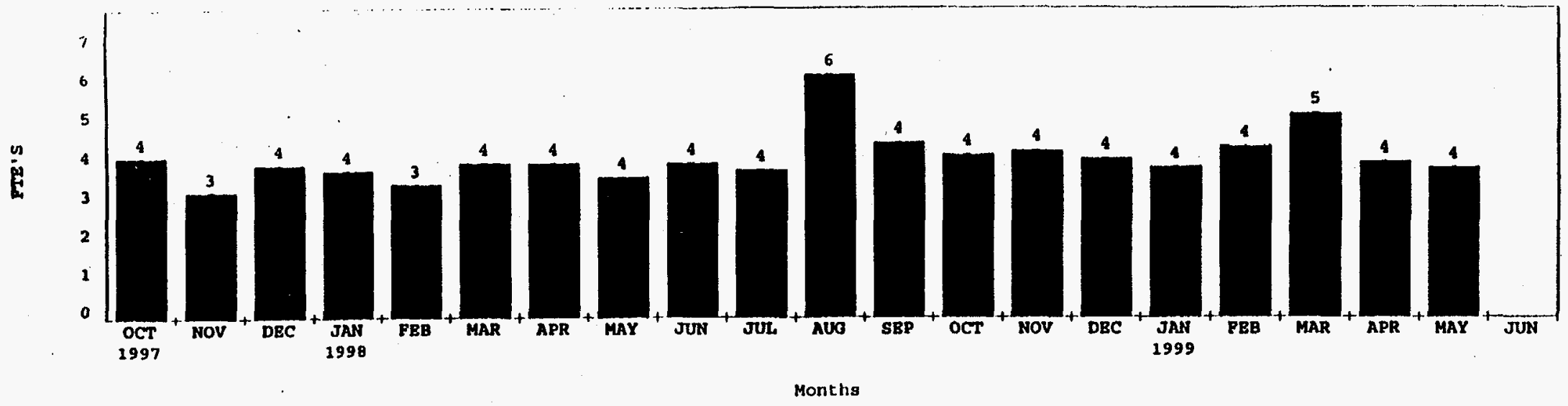

$1=m 921000$

TOTAL, MANUAL RESOURCES

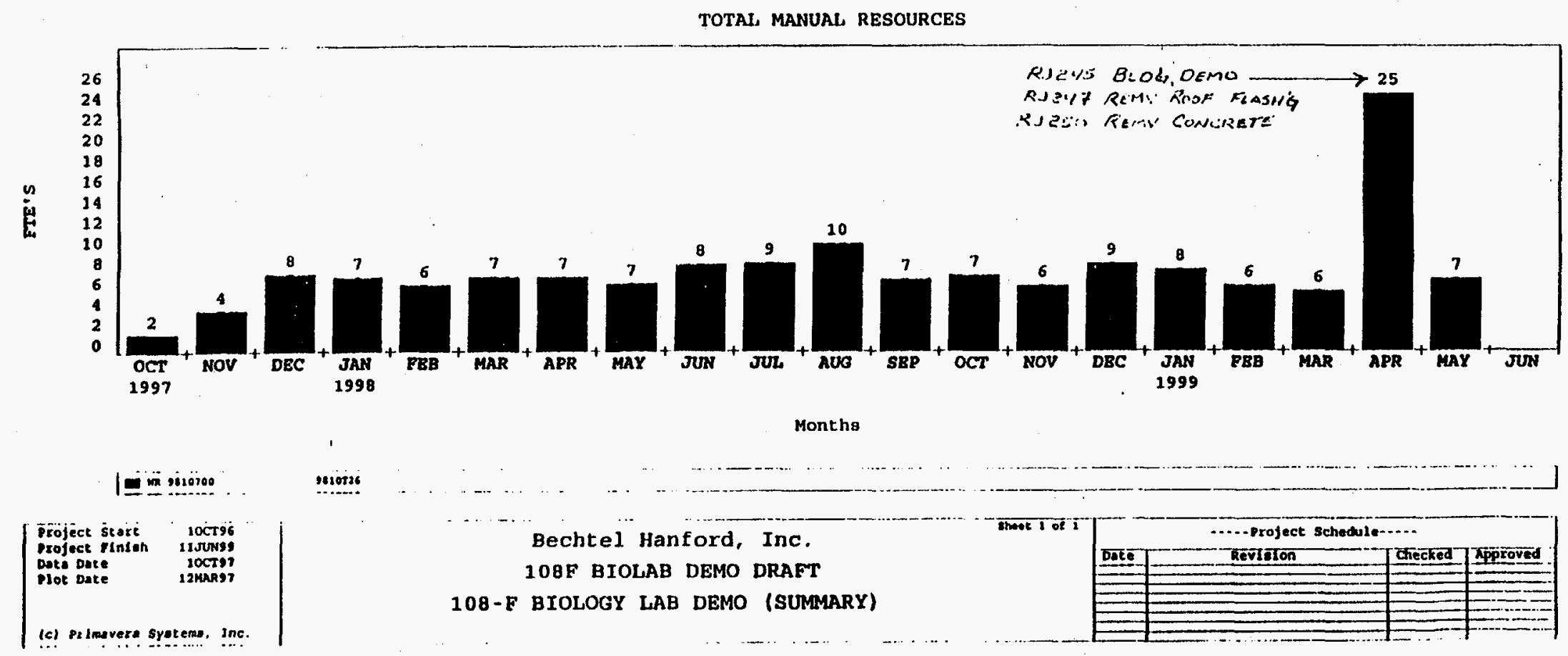


DOE/RL-97-29

Rev. 0
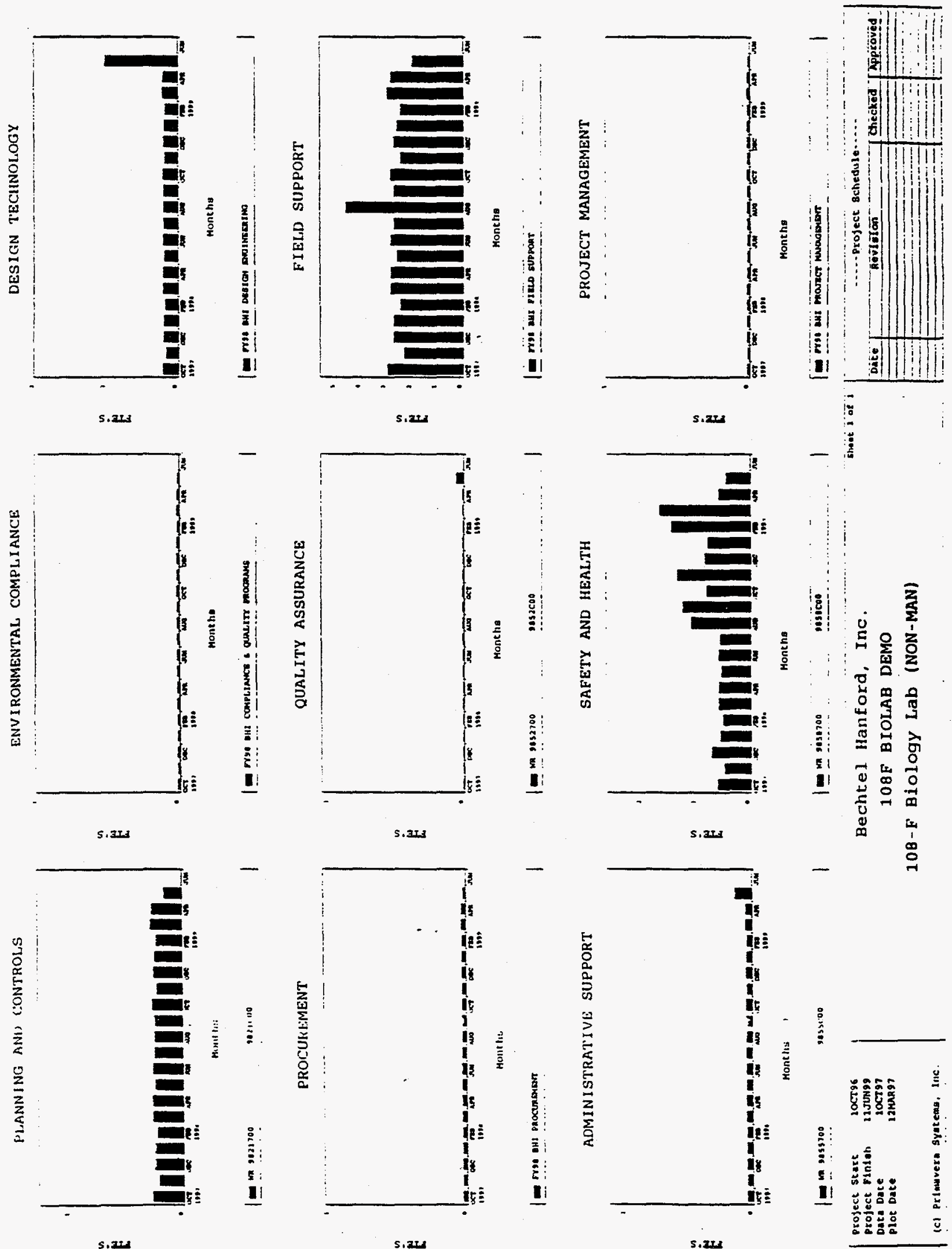

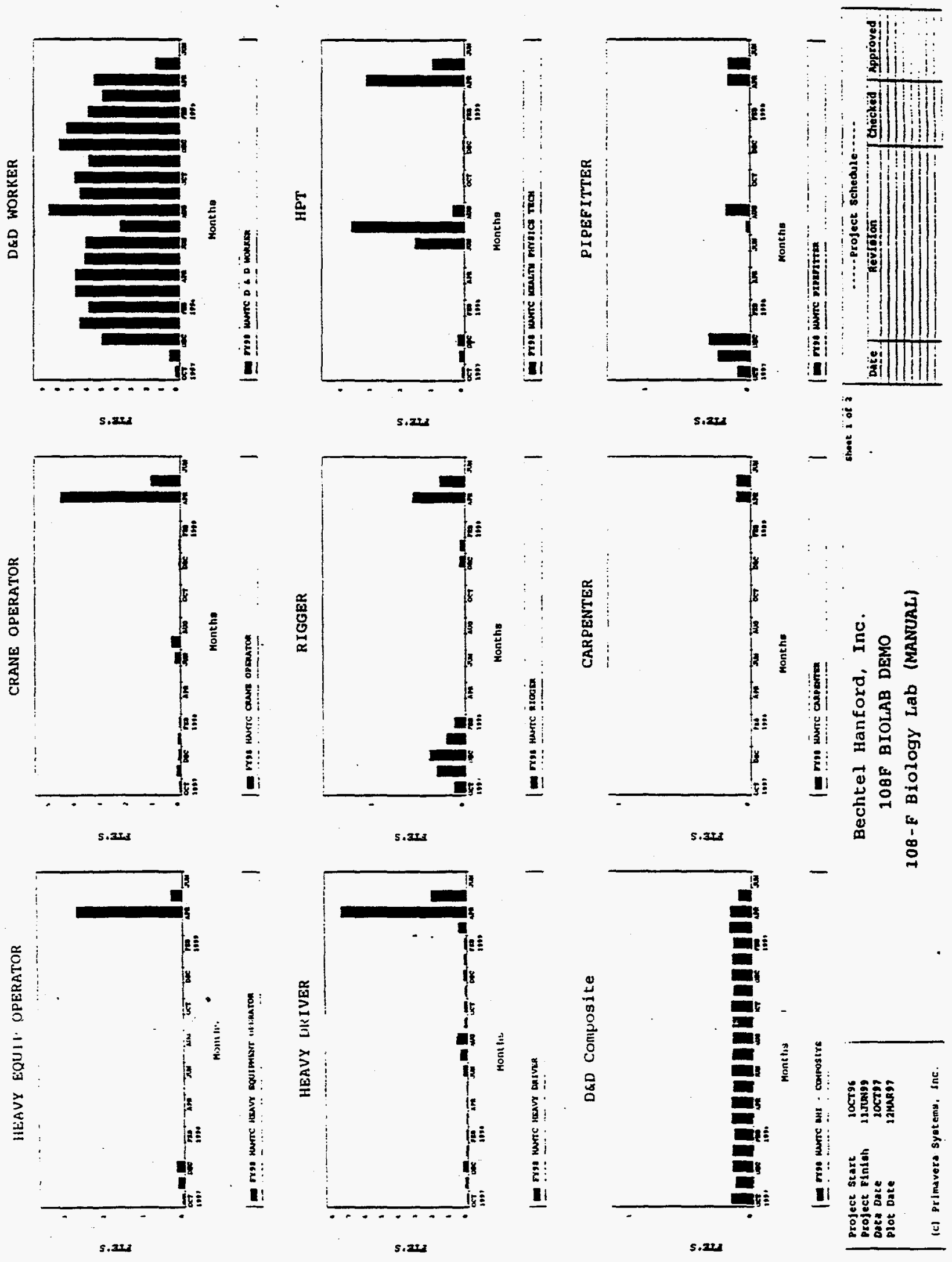


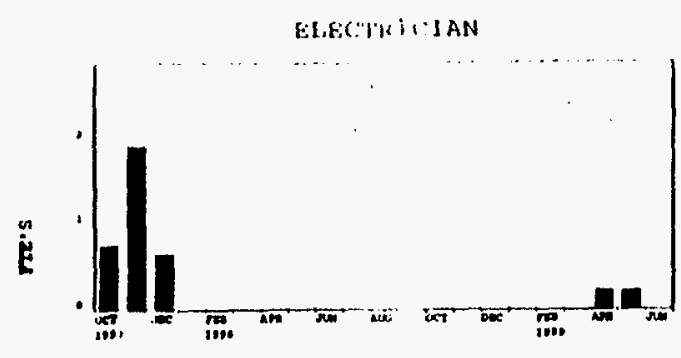

Months

I

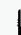

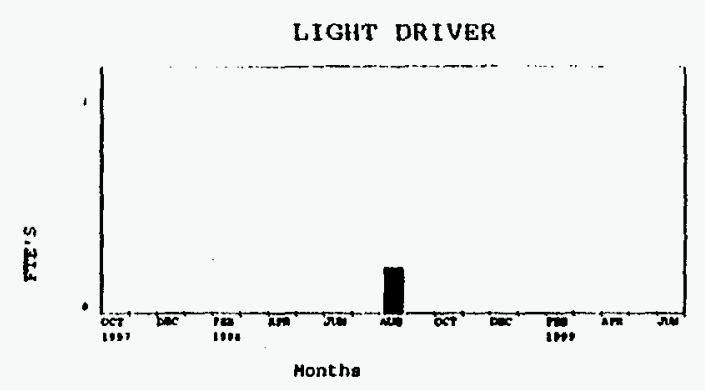

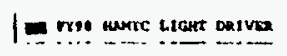

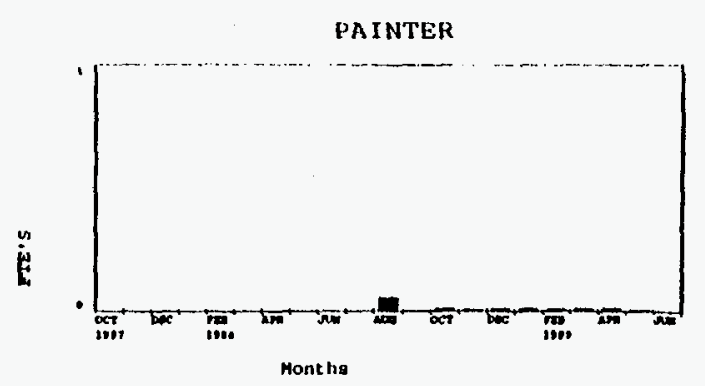

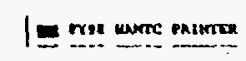

1

罗
Bechtel Hanford, Inc.
108 F BIOLAB DEMO
108-F Biology Lab (MANUAL)


DOE/RL-97-29

Rev. 0

\section{DISTRIBUTION}

ONSITE (32 copies)

U.S. Department of Energy,

Richland Operations Office

D. C. Smith (10) H0-12

ERC Team

D. M. Brehm X0-23

A. A. Freitag H0-18

S. M. Hamblin X0-17

D. A. Harrow $\quad \mathrm{X} 7-02$

N. C. Little X5-53

J. J. McGuire X5-53

M. A. Mihalic X5-53

T. J. Rodovsky (4) X5-53

J. E. Rugg X5-53

D. S. Smith $\quad X 5-53$

D. J. Stroup $\quad$ X0-34

Administrative Record H0-09

D\&D Project Files X5-53

Document Information Services (4) H0-09

Hanford Technical Library (2) P8-55 